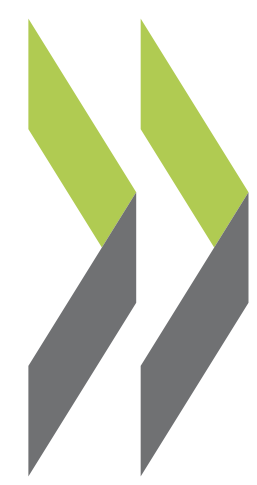

OECD Economics Department Working Papers No. 1562

Empirical links between Boris Cournède, housing markets and economic resilience

Sahra Sakha,

Volker Ziemann 


\section{EMPIRICAL LINKS BETWEEN HOUSING MARKETS AND ECONOMIC RESILIENCE}

\section{ECONOMICS DEPARTMENT WORKING PAPERS No. 1562}

By Boris Cournède, Sahra Sakha, Volker Ziemann

OECD Working Papers should not be reported as representing the official views of the OECD or of its member countries. The opinions expressed and arguments employed are those of the author(s).

Authorised for publication by Alain de Serres, Deputy Director, Policy Studies Branch, Economics Department.

Document available in pdfformat only.

All Economics Department Working Papers are available at www.oecd.org/eco/workingpapers.

\section{JT03449884}


OECD Working Papers should not be reported as representing the official views of the OECD or of its member countries. The opinions expressed and arguments employed are those of the author(s).

Working Papers describe preliminary results or research in progress by the author(s) and are published to stimulate discussion on a broad range of issues on which the OECD works.

Comments on Working Papers are welcomed, and may be sent to OECD Economics Department, 2 rue André Pascal, 75775 Paris Cedex 16, France, or by e-mail to eco.contact@oecd.org.

All Economics Department Working Papers are available at www.oecd.org/eco/workingpapers

The statistical data for Israel are supplied by and under the responsibility of the relevant Israeli authorities. The use of such data by the OECD is without prejudice to the status of the Golan Heights, East Jerusalem and Israeli settlements in the West Bank under the terms of international law.

On 25 May 2018, the OECD Council invited Colombia to become a Member. At the time of preparation the deposit of Colombia's instrument of accession to the OECD Convention was pending and therefore Colombia does not appear in the list of OECD Members and is not included in the OECD zone aggregates.

(C) $\operatorname{OECD}(2019)$

You can copy, download or print OECD content for your own use, and you can include excerpts from OECD publications, databases and multimedia products in your own documents, presentations, blogs, websites and teaching materials, provided that suitable acknowledgment of OECD as source and copyright owner is given. All requests for commercial use and translation rights should be submitted to rights@oecd.org. 


\section{ABSTRACT/RÉSUME \\ Empirical Links Between Housing Markets and Economic Resilience}

Housing markets, which are large and subject to sharp swings, shape to a great extent countries' exposure to economic crises and their capacity to recover from them. This paper analyses the transmission of housing-related shocks to the real economy: it investigates the role that policy plays in (a) mitigating or amplifying shocks and (b) facilitating or hampering a recovery. It considers macroprudential measures, rental regulation, taxation and land use restrictions. The aim is to investigate, which housing policy-related reforms can foster greater economic resilience. Among other results, it finds that a tighter macroprudential stance is generally linked to a lower likelihood of economic crisis and that higher effective rates of housing taxation are associated with smoother housing cycles.

JEL Classification codes: E37, E5, R31

Keywords: Housing, resilience, macroprudential policy, rent regulation, taxation, land use policy

$* * * * * * * * *$

\section{Relations empiriques entre marché du logement et résilience de l'économie}

De taille importante et sujets à de brusques retournements de cycle, les marchés du logement sont, dans une large mesure, un déterminant de l'exposition d'un pays aux crises économiques et de sa capacité à s'en redresser. On analyse dans cette étude la transmission des chocs liés au secteur du logement dans l'économie réelle et l'on s'interroge sur le rôle des politiques publiques et comment elles (a) atténuent ou amplifient les chocs, et (b) facilitent ou entravent le redressement de l'économie. Sont examinées les mesures macroprudentielles, la réglementation locative, la fiscalité et les restrictions à l'occupation des sols. L'objectif est d'examiner, parmi les réformes de la politique du logement, celles qui sont susceptibles d'accroître la résilience de l'économie. Entre autres résultats, on observe qu'une orientation macroprudentielle plus restrictive va généralement de pair avec une plus faible probabilité de crise économique, et qu'une augmentation des taux d'imposition effectifs de l'immobilier résidentiel s'accompagne d'un lissage des cycles sur le marché du logement.

Classification JEL : E37, E5, R31

Mots-clés : Logement, resilience, politiques macroprudentielles, regulation du marché locatif, taxation, réglementation foncière 


\section{Table of contents}

Empirical Links between Housing Markets and Economic Resilience ............................................. 6

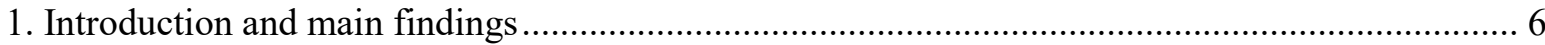

2. Housing markets and resilience: A framework for the analysis ................................................... 8

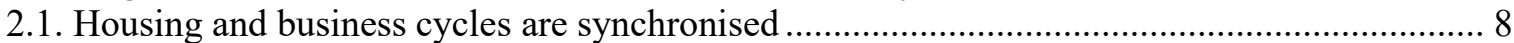

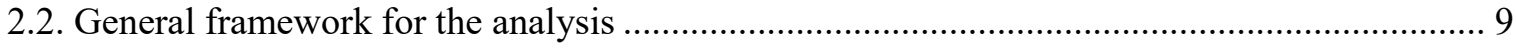

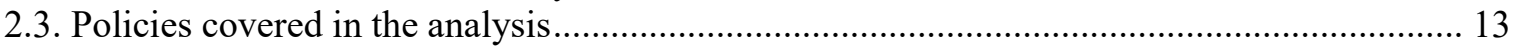

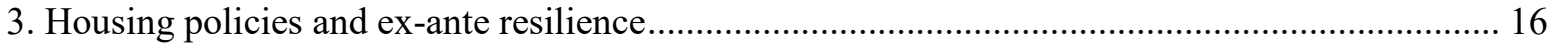

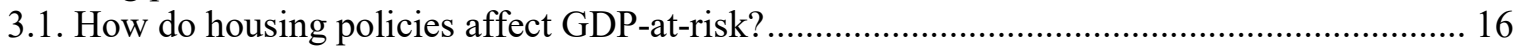

3.2. Estimation using quantile regressions and empirical results ................................................. 17

3.3. Estimation using a probabilistic model of a severe downturn and empirical results .............. 21

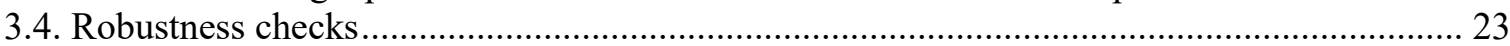

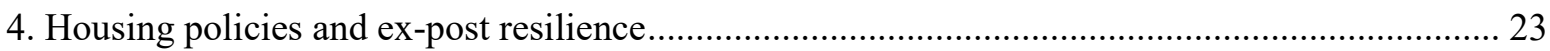

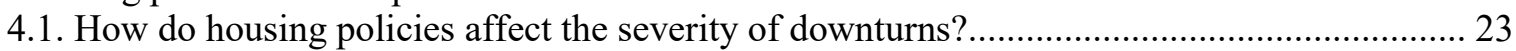

4.2. How do policies affect the transmission of housing shocks? ................................................. 24

4.3. Gauging causality: Measuring the impact of policy changes on real, financial and housing

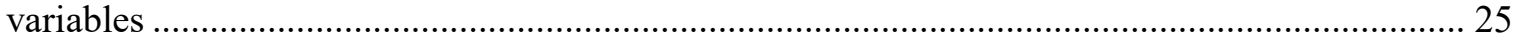

References ................................................................................................................................................ 29

Annex A. Coverage of outcome variables................................................................................................ 35

Annex B. Resilience indicators .................................................................................................................... 36

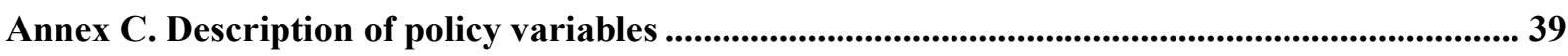

Annex D. Gauging land use policies from urban sprawl data.............................................................. 40

Annex E. Summary statistics of policy variables.......................................................................................... 42

Annex F. Identified episodes of severe downturns .................................................................................. 44

Annex G. Housing policies and resilience indicators................................................................................... 46

\section{Tables}

Table 1. Main effects of tightening housing-related policies on resilience ......................................... 8

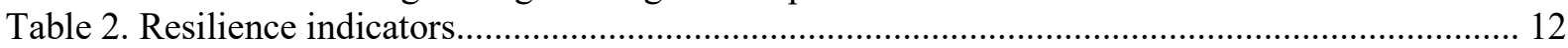

Table 3. Macroprudential policies and GDP growth quantile regression.......................................... 19

Table 4. Housing market policies and GDP growth quantile regression ............................................... 20

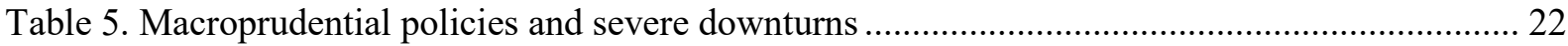

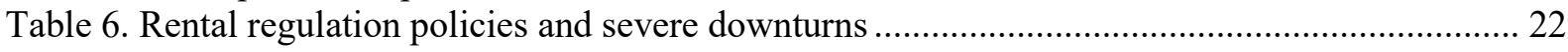

Table 7. How do housing policies affect the transmission of house price corrections? ........................ 25

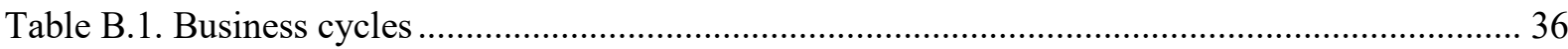

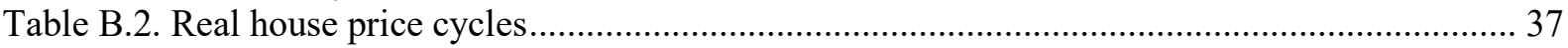

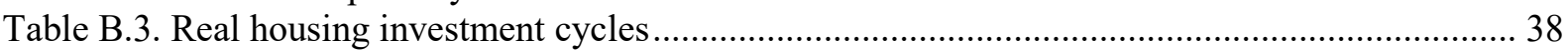

Table D.1. Urban sprawl indicators - principal component analysis ................................................ 40 


\section{Figures}

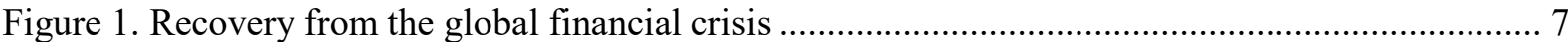

Figure 2. Cyclical behaviour of output, house prices and residential investment .................................. 9

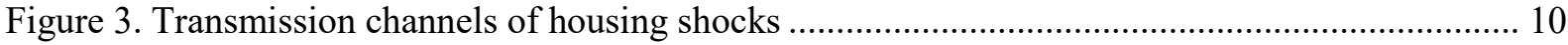

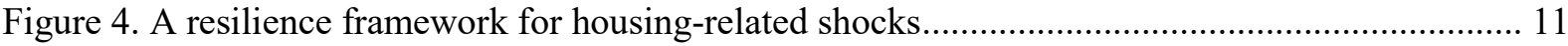

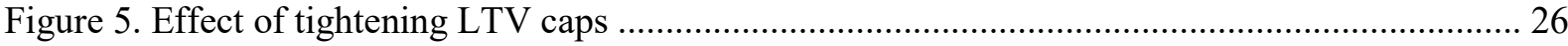

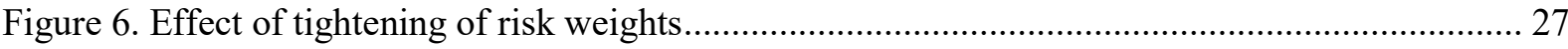

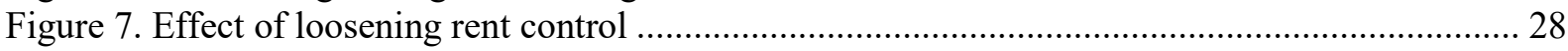




\title{
Empirical Links between Housing Markets and Economic Resilience
}

\author{
By Boris Cournède, Sahra Sakha, Volker Ziemann ${ }^{1}$
}

\section{Introduction and main findings}

1. Housing market developments influence the business cycle and macroeconomic trends. Changes in house prices, rents and mortgage interest rates prompt variations in household wealth, income and expenditure that often have a sizeable impact on aggregate demand and inflation. Furthermore, house price fluctuations affect residential investment, and thereby GDP, as well as living standards depending on the adequacy of the construction response. Countries with sharper declines in residential investment in the aftermath of the global financial crisis generally needed more time to recover from the crisis and regain the pre-crisis level of real GDP (Figure 1).

2. This paper provides empirical analyses of the transmission of housing-related shocks to the real economy and the roles that policy plays in (a) mitigating or amplifying shocks and (b) facilitating or hampering a recovery. The empirical investigations in the present paper provide the analytical underpinning for the policy section of a companion report, which takes stock of current trends in housing markets, presents estimates of associated macroeconomic risks and discusses policy implications (Cavalleri, Cournède and Ziemann, 2019[1]).

3. Housing has other important social and well-being aspects. It fulfils a basic human right for shelter, and contributes to the well-being of families and entire communities. Future OECD analysis is planned to explore these dimensions.

1. This report contributes to the OECD Housing Project. The authors are members of the OECD Economics Department. The Working Party No. 1 on Macroeconomic and Structural Policy Analysis discussed an earlier version of this paper. The authors thank members of the Working Party and in particular its Chair, Mr. Arent Skjæveland (Norwegian Ministry of Finance), for their feedback. The authors are indebted to Laurence Boone, Peter Hoeller, Åsa Johansson, Luiz de Mello and Alain de Serres (OECD Economics Department) for their guidance and to Aida Caldera Sanchez (OECD Economics Department) for her review. They express their gratitude to Sonya $\mathrm{Lu}$ (Georgetown University) for her work on the database of macro-prudential measures. They would like to thank Christophe André, Andrew Barker, Sebastian Barnes, Isabelle Joumard, Tomasz Kozluk, Douglas Sutherland (OECD Economics Department) and Walid Oueslati (OECD Environment Directorate) for their comments. The authors are grateful to Aman Johal and Celia Rutkoski (OECD Economics Department) for editorial support. They can be reached at boris.cournede@oecd.org, sahra.sakha@oecd.org and volker.ziemann@oecd.org. 
Figure 1. Recovery from the global financial crisis

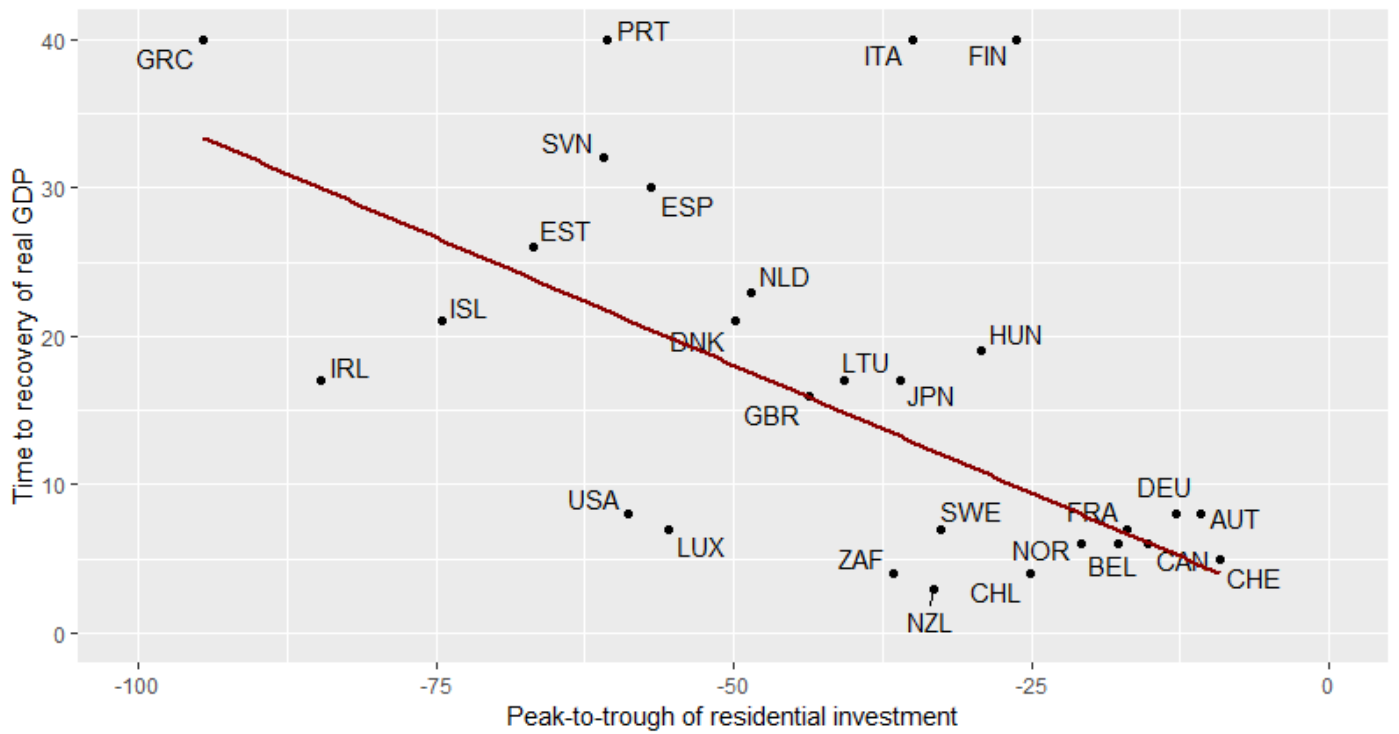

Note: Time to recovery in quarters (equals 40 if not recovered by 2018). Peak-to-trough in \% of pre-crisis peak. Source: OECD Economic Outlook database.

4. To do so, this study provides new empirical evidence on the links between macroprudential and other housing policies, vulnerability to crises (ex-ante resilience) and recoveries from them (ex-post resilience). This paper complements past OECD work on housing and resilience (Andrews, Caldera Sánchez and Johansson, 2011; Caldera Sánchez and Roehn, 2016; Hermansen and Roehn, 2016), by drawing new policy lessons for the design of housing and macroprudential policies. It also lays the foundation for future work on housing and economic performance. A companion paper provides additional material on the empirical analysis (Sakha, 2019, forthcoming $\left.{ }_{[2]}\right)$.

5. The main findings are:

- Tighter loan-to-value (LTV) caps are associated with a reduced likelihood of severe downturns but also slower recoveries and less strong growth. Their effects on the tail risk of real output are inconclusive. Overall, the evidence confirms earlier results that LTVs seem to entail a trade-off between growth and crisis risk.

- More demanding capital requirements also appear to involve the same trade-off, as they are linked with a reduced incidence of downturns but lower median growth. Risk weights that penalise risky mortgages more are tentatively linked with stronger episodes of positive growth, which would be consistent with the hypothesis that they encourage a more efficient allocation of credit.

- More stringent rental market regulations are associated with severe downturns that are more likely and more protracted, which may be related to bottlenecks in housing supply and lower labour mobility. On the other hand, rental regulations seem to achieve their objective of protecting tenants against adverse economic shocks, as extreme output losses seem to be reduced by more stringent tenure security.

- Higher effective taxation of housing is associated with less severe downturns. Moreover, countries with higher taxation experience more moderate house price fluctuations and smoother residential construction cycles. The findings are based 
on a cross-section of marginal effective tax rates on owner-occupied and rental investment property. Time series data would be highly valuable to confirm these cross-sectional findings.

- Policy indicators for land use regulations are not readily available. The paper draws on outcome measures of urban sprawl and develops composite indicators for urban sprawl, densification and zoning restrictiveness. Tentative results suggest that zoning restrictions hinder booms but also recoveries of housing investment.

Table 1. Main effects of tightening housing-related policies on resilience

\begin{tabular}{|c|c|c|c|c|}
\hline & $\begin{array}{l}\text { GDP-at- } \\
\text { risk }\end{array}$ & Crisis risk & $\begin{array}{c}\text { Severity of } \\
\text { downturn }\end{array}$ & $\begin{array}{c}\text { Strength of } \\
\text { recovery }\end{array}$ \\
\hline LTV caps & & 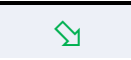 & & $\unlhd$ \\
\hline Capital requirements for mortgage loans & & $\unlhd$ & & $\gtrsim$ \\
\hline Rental regulation & 邓 & $\gtrsim$ & $\gtrsim$ & \\
\hline Property taxation & & & $\unlhd$ & \\
\hline
\end{tabular}

Note: The table summarises the results of empirical exercises performed throughout the study. Only significant results are displayed. GDP-at-risk refers to the bottom $5 \%$ quantile of the distribution of quarterly real GDP growth. Tightening means increases in policy indicators, except for LTV caps where a decrease of the policy value signifies a tightening. Green arrows show good outcomes, red ones bad outcomes. Table 7 provides summary indications about the results relating to the housing transmission channels of policy effects.

6. The rest of the paper is organised as follows. The next section lays out the comovement between housing and economic cycles before setting out a general framework for the analysis. The following section describes what kind of housing policies countries have been using and expected effects based on the literature. Section 4 assesses the link between housing policies and vulnerability to shocks (ex-ante resilience). Section 5 provides an empirical analysis of the relationship between policies and countries' capacity to recover from shocks (ex-post resilience).

\section{Housing markets and resilience: A framework for the analysis}

\subsection{Housing and business cycles are synchronised}

7. Links between the housing market and the business cycle can affect the level of economic activity and the economy's ability to recover quickly to long-term growth after a shock (Andrews, Caldera Sánchez and Johansson, 2011 $1_{[3]}$ ). To shed light on the synchronisation of housing markets and business cycles, Figure 2 depicts local regressions of real GDP, the output gap, real house prices and residential investment around business cycles peaks (Panel A), deviation cycle peaks (Panel B), peaks in real house prices (Panel C) and peaks in residential investment (Panel D). Prior to business cycle recessions, residential investment is flat or falling (Figure 2, Panel A). In contrast, residential investment and real house prices move together with real output prior to turning points of the output gap, which is when growth falls below potential without necessarily trigging a recession (Panel B). In both cases, residential investment falls after the peak but, in line with real output, the fall is more substantial after business cycle peaks. Real house prices tend to lead real output when recessions occur but lag real output when the output gap peaks. This is partly due to the lag between peaks in output gaps and real GDP since growth falls below potential before becoming negative. In a nutshell, for the average recession, 
first the growth rate falls below potential then real house prices peak and then the recession kicks in.

8. Similar to real output, one can define turning points in the housing market using real house prices or residential investment. The results suggest that declines in real house prices trigger similar declines in residential investment (Panel C) but that declines in residential investment affect real house prices and output much less (Panel D).

Figure 2. Cyclical behaviour of output, house prices and residential investment
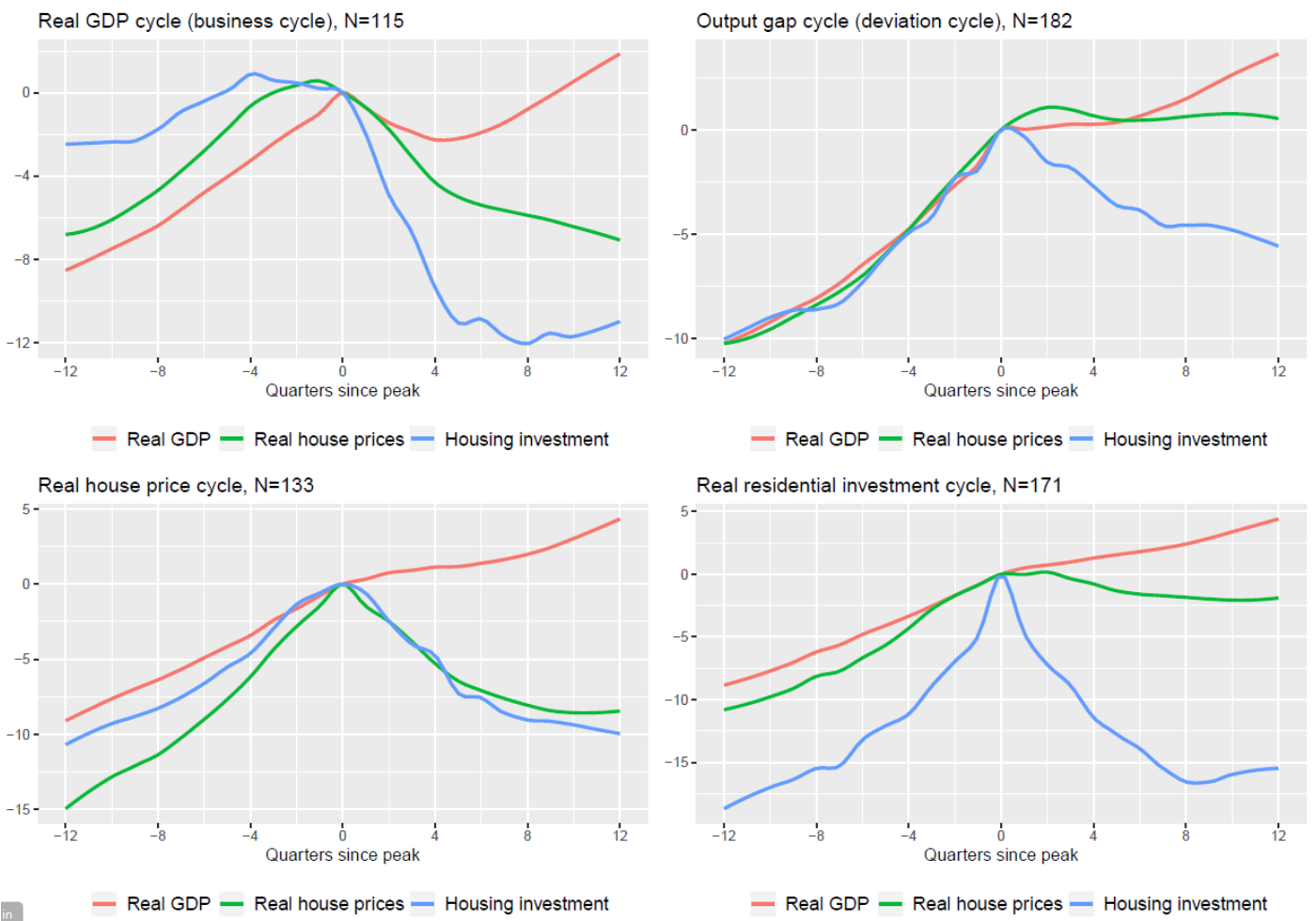

Note: Peaks are obtained using the Harding-Pagan (quarterly Bry-Boschan) business cycle dating procedure (Harding and Pagan, 2002[4]).

Source: OECD Economic Outlook database and OECD Analytical House Price database.

\subsection{General framework for the analysis}

9. Figure 3 depicts a simple framework for the transmission of housing demand shocks. Such shocks can come from demography, especially migration, changes in disposable income, house prices, interest rates or credit conditions. Shocks can stem from domestic factors, but also international ones such as shifts in global capital flows (Miles, $\left.2019_{[5]}\right)$. When a housing demand shock occurs, housing supply rigidities lead to either an increase in vacancies (negative demand shock) or scarcity (positive demand shock), which results in housing investment and house price adjustments to clear housing markets. The extent to which the housing demand shock affects prices depends on the financial cycle (e.g. initial over or under-valuation of house prices, credit conditions) but also on policies (inelastic supply due to zoning regulations, rent control, etc.) and cyclical or structural variables (e.g. construction costs, infrastructure). 
Figure 3. Transmission channels of housing shocks

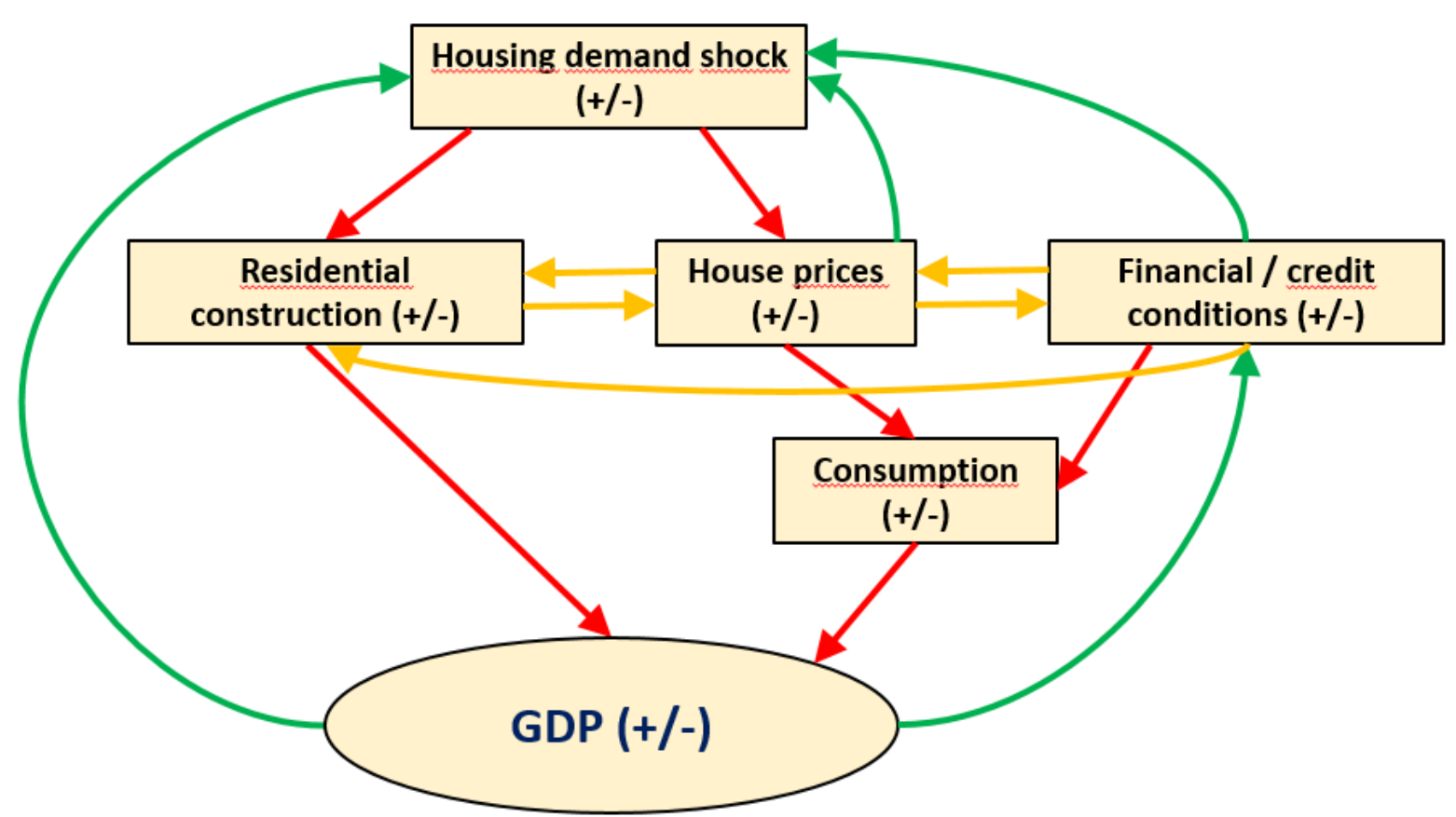

10. Changes in house prices obviously directly influence housing demand, but they also have indirect effects through the financial system. Movements in house prices indeed have a strong impact on household balance sheets. Financial and credit conditions react to changes in household balance sheets (Fissel, Hanweck and Sanders, 2018 ${ }_{[6]}$ ), affecting, for instance, non-performing loans and loan-to-value ratios with opposite effects for incumbents and potential new homeowners.

11. Changes in house prices also affect consumption depending on the size and institutional set-up of mortgage markets. For instance, amortisation requirements and the choice between fixed and variable interest rate loans determine, ceteris paribus, whether the effect on consumption is pro or counter-cyclical. The pass-through also depends on the rate of homeownership. Current homeowners benefit (suffer) from the wealth and collateral (i.e. home-equity withdrawal) effect, while future homeowners face increasing (decreasing) saving needs to finance future down-payments. The experience of OECD countries shows that there is considerable co-movement between housing and business cycles.

12. This study assesses how housing-related policies can affect the transmission channels depicted in Figure 3 with the aim to find out, which policies affect the build-up of vulnerabilities, reduce the severity of crises and foster an economy's capacity to recover from them. Figure 4 lays out a simple conceptual framework for the analysis by disentangling ex-ante (vulnerability to shocks) and ex-post resilience. The functioning and characteristics of housing markets differ considerably across countries and so do related policies. The global financial crisis has triggered a wave of policy innovations many of which target the housing market directly. In particular, macroprudential policies have emerged as a means of leaning against credit bubbles and enhancing financial stability. Other housing-related policies considered in this study include property taxation, rent control and tenure protection, social housing, housing subsidies and zoning regulations. 
Figure 4. A resilience framework for housing-related shocks

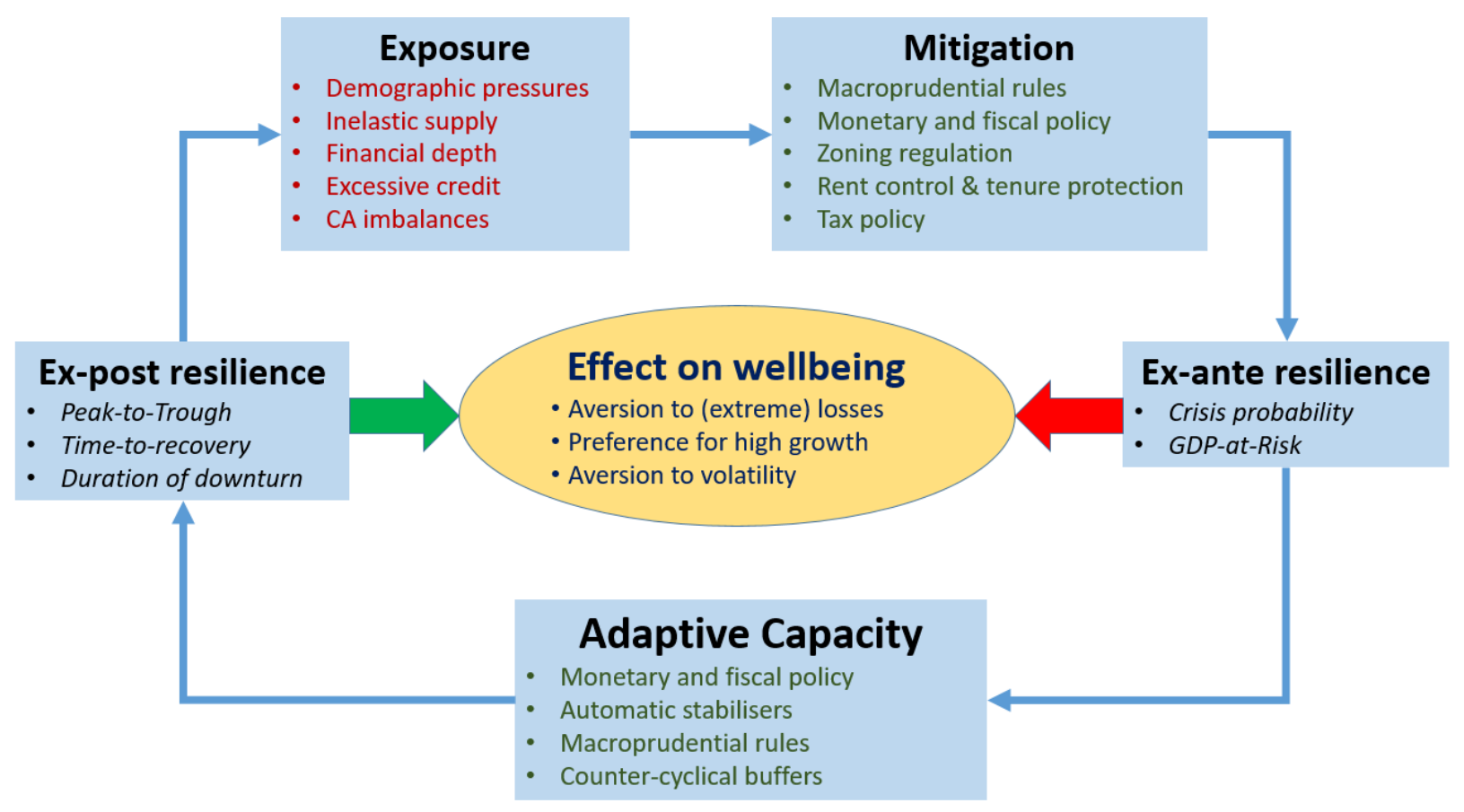

13. Ex-ante resilience will be assessed by i) the probability that a large shock occurs, and ii) GDP-at-risk, which measures the maximum loss in output with a certain likelihood (e.g. 95\%). Ex-post resilience, on the other hand, will be assessed through measures for the i) severity of downturns (peak-to-trough), ii) the duration of downturns and iii) the time needed to recover, that is, regain the pre-crisis level of output. Table 2 depicts these indicators for deviation cycles (de-trended quarterly growth rates of real GDP) for 45 countries using for illustrative purposes the period from 1990 to 2017. Resilience indicators for business cycles (real GDP), real house price and housing investment cycles are shown in Annex B. 
Table 2. Resilience indicators

\begin{tabular}{|c|c|c|c|c|c|c|}
\hline & \multicolumn{2}{|c|}{ Ex-ante resilience } & \multicolumn{3}{|c|}{ Ex-post resilience } & \multirow[b]{2}{*}{$\begin{array}{c}\text { Number of } \\
\text { peaks }\end{array}$} \\
\hline & $\begin{array}{l}\text { Crisis prob- } \\
\text { ability }\end{array}$ & Q5 & Duration (bust) & $\begin{array}{c}\text { Peak-to- } \\
\text { trough }\end{array}$ & $\begin{array}{l}\text { Strength of } \\
\text { recovery }\end{array}$ & \\
\hline ARG & 22.7 & -4.3 & 7.2 & -11.2 & 6.3 & 6 \\
\hline AUS & 2.7 & -0.9 & 5.1 & -1.3 & 0.8 & 10 \\
\hline AUT & 2.7 & -0.8 & 5.9 & -2.5 & 1.4 & 8 \\
\hline BEL & 3.6 & -0.9 & 4.0 & -1.7 & 1.1 & 9 \\
\hline BRA & 11.6 & -1.9 & 8.7 & -6.4 & 1.5 & 6 \\
\hline CAN & 4.5 & -1.1 & 5.0 & -2.4 & 1.1 & 8 \\
\hline $\mathrm{CHE}$ & 3.7 & -1.0 & 5.3 & -2.3 & 1.6 & 8 \\
\hline $\mathrm{CHL}$ & 7.1 & -1.7 & 7.2 & -4.5 & 2.6 & 6 \\
\hline $\mathrm{CHN}$ & 2.7 & -0.8 & 12.2 & -2.8 & 1.6 & 5 \\
\hline $\mathrm{COL}$ & 7.4 & -1.4 & 5.0 & -3.1 & 1.3 & 5 \\
\hline CRI & 3.8 & -1.2 & 4.2 & -2.5 & 0.8 & 7 \\
\hline CZE & 5.9 & -1.1 & 7.5 & -4.0 & 3.4 & 5 \\
\hline DEU & 6.3 & -1.3 & 4.8 & -2.8 & 0.9 & 9 \\
\hline DNK & 5.4 & -1.5 & 4.9 & -2.9 & 1.7 & 10 \\
\hline ESP & 7.1 & -1.4 & 15.7 & -6.2 & 2.6 & 3 \\
\hline EST & 6.9 & -3.7 & 7.5 & -14.2 & 6.6 & 2 \\
\hline FIN & 11.6 & -1.7 & 6.0 & -4.3 & 1.7 & 6 \\
\hline FRA & 2.7 & -0.7 & 6.7 & -2.1 & 1.3 & 6 \\
\hline GBR & 4.5 & -0.9 & 4.0 & -1.5 & 1.3 & 10 \\
\hline GRC & 10.7 & -1.7 & 11.2 & -7.9 & 2.3 & 5 \\
\hline HUN & 5.6 & -0.9 & 4.2 & -3.4 & 0.4 & 5 \\
\hline IDN & 4.6 & -1.8 & 4.0 & -8.3 & 3.3 & 5 \\
\hline IND & 8.6 & -1.5 & 5.7 & -3.5 & 2.5 & 6 \\
\hline IRL & 11.6 & -3.6 & 5.3 & -7.2 & 5.0 & 7 \\
\hline ISL & 15.2 & -3.6 & 4.3 & -5.1 & 4.6 & 10 \\
\hline ISR & 8.7 & -1.5 & 5.0 & -4.2 & 2.3 & 6 \\
\hline ITA & 3.6 & -1.1 & 4.3 & -2.9 & 1.3 & 7 \\
\hline JPN & 7.1 & -1.4 & 4.7 & -3.6 & 1.8 & 9 \\
\hline KOR & 8.0 & -1.7 & 4.4 & -4.2 & 2.2 & 9 \\
\hline LTU & 4.7 & -1.4 & 3.8 & -4.9 & 1.9 & 5 \\
\hline LUX & 14.6 & -2.4 & 5.2 & -5.7 & 1.9 & 6 \\
\hline LVA & 11.4 & -3.5 & 5.0 & -6.8 & 2.2 & 6 \\
\hline MEX & 4.3 & -1.4 & 4.0 & -2.7 & 1.3 & 9 \\
\hline NLD & 2.7 & -1.0 & 6.3 & -3.1 & 1.3 & 7 \\
\hline NOR & 3.6 & -1.4 & 7.3 & -3.1 & 2.2 & 7 \\
\hline NZL & 6.3 & -1.7 & 4.0 & -2.8 & 0.6 & 11 \\
\hline POL & 6.7 & -1.4 & 6.3 & -3.9 & 3.0 & 6 \\
\hline PRT & 9.8 & -1.3 & 8.8 & -5.8 & 2.3 & 5 \\
\hline RUS & 11.8 & -2.2 & 7.3 & -8.4 & 2.5 & 3 \\
\hline SVK & 5.7 & -1.7 & 6.6 & -4.8 & 1.3 & 5 \\
\hline SVN & 6.6 & -1.5 & 6.0 & -5.6 & 1.0 & 4 \\
\hline SWE & 6.3 & -1.2 & 7.2 & -4.0 & 3.5 & 5 \\
\hline TUR & 13.0 & -4.2 & 6.7 & -9.0 & -0.1 & 6 \\
\hline USA & 4.5 & -1.1 & 6.0 & -2.3 & 1.4 & 7 \\
\hline ZAF & 4.4 & -1.0 & 6.6 & -2.7 & 1.3 & 5 \\
\hline
\end{tabular}

Note: Based on de-trended growth rate of real GDP from 1990 to 2017. Darker shading indicates more extreme values for the respective indicator. Crisis probability denotes the probability of experiencing a cumulative two percentage point decline over two consecutive quarters. $Q 5$ denotes the $5^{\text {th }}$ percentile of the distribution. Busts refer to periods leading from a peak to a trough. Peaks are obtained using the Harding-Pagan (quarterly Bry-Boschan) business cycle dating procedure (Harding and Pagan, $\left.2002_{[4]}\right)$. Strength of recovery denotes growth over $n$ quarters, $n$ being the duration of the preceding bust period. Duration is in quarters, all other indicators are in percentage points. For ex-post resilience indicators, the table shows averages over observed cycles.

Source: OECD Economic Outlook Database and own calculations. 


\subsection{Policies covered in the analysis}

This subsection goes over the indicators used in the empirical analysis and summarises their expected effects based on the literature. The companion paper provides a more extensive discussion of the extent to which countries are using these policies and what existing literature suggests about the impact of these policies on economic resilience (Cavalleri, Cournède and Ziemann, 2019 $\left.9_{[1]}\right)$.

\subsubsection{Macroprudential regulation}

Macroprudential policy aims to prevent financial threats to economic stability by restraining the build-up of systemic risk. Macroprudential instruments can work on the side of borrowers or lenders. On the borrower side, the most frequently used tools include: ${ }^{2}$

- Loan-to-value ratios (LTVs) cap housing loans to a certain proportion of the house value. A shortcoming of LTVs is that the denominator, housing valuation, moves with housing cycles, which reduces the constraint imposed by LTVs. LTVs nonetheless appear to be capable of moderating boom-bust cycles in generalequilibrium as well as agent-based models (Baptista et al., 2016 ${ }_{[7]}$; Laliotis and Población, 2016 ${ }_{[8]}$; Kelly, McCann and O'Toole, 2018 ${ }_{[9]}$; Funke and Paetz, 2016 $6_{[10]}$; Balfoussia, Dellas and Papageorgiou, 2018 $8_{[11]}$. Furthermore, a number of empirical studies have found that LTVs moderate housing cycles (Kuncl, 2016 [12]; Ferrero, Harrison and Nelson, 2018[13]; BIS, 2018 ${ }_{[14]}$; Armstrong, Skilling and Yao, $\left.2019_{[15]}\right)$.

- Debt-service-to-income ratios (DSTIs) require households to not pay more than a certain proportion of their income to service their housing loans. In some countries, DSTIs are based on total rather than only housing debt servicing costs. Debtservice-to-income ratios are promising, especially as they could avoid the problem intrinsic to LTV caps that their denominator, house valuations, gets inflated during a housing bubble (Greenwald, 2018 $\left.{ }_{[16]}\right)$. The empirical literature looking at DSTIs and LTVs taken together has generally found that they contain credit growth (Cerutti, Claessens and Laeven, 2017 [17]; Claessens, Ghosh and Mihet, 2013 ${ }_{[18]}$; Alam et al., 2019 [19]; Poghosyan, 2019[20]).

14. Typically used macroprudential policy tools working on the side of lenders include:

- A key policy lever is the minimum capital ratio with which banks must fund housing loans. The strength of this requirement is determined by the combination of minimum capital ratios and risk weights:

- Minimum capital ratios set floors for the ratios of different measures of capital (core equity, equity, core Tier I, Tier I, total capital) over risk-weighted assets.

- Risk weights (RW) for housing loans held on bank balance sheets can vary based on loan-to-value ratios. Higher risk weights make it more costly for banks to provide housing loans, which can be expected to contain housing booms. A case study for Israel indeed found that a hike in risk weights contained house prices (Laufer et al., 2018 $8_{[21]}$ ). The empirical literature on the implications of

2. Other potential tools are restrictions on the use of variable-rate or foreign currency mortgages.

Lack of data availability prevented their inclusion in the analysis. 
risk weight changes on restricting credit growth found ambiguous results. Aiyar, Calomiris and Wieladek $\left(2014_{[22]}\right)$ using bank-level UK data showed that lenders unaffected by tighter capital requirements (foreign bank branches) offset one third of the impact of the tightening.

- Other lender-side policy levers with relevance to housing are minimum liquidity requirements (mostly the liquidity coverage ratio and net stable funding ratio), which aim to reduce liquidity mismatches between bank assets (including housing loans) and financing. Active use of these tools, which spread with the implementation of the Basel III framework, is, however, too recent to have produced sufficient experience for their inclusion in the econometric analysis below.

15. The literature is still split regarding the effect of macroprudential measures on average growth. Some cross-country contributions point to a trade-off between stability and long-term economic growth. For instance, Kim and Mehrotra $\left(2018_{[23]}\right)$, using a VAR model, find a negative effect of changes in macroprudential policies on output and inflation in the Asia-Pacific region. Similarly, Caldera Sánchez and Roehn (2016[24]), using quantile regression estimation, show that LTV caps reduce the median and upper part of the distribution of output growth. By contrast, Boar et al. $\left(2017_{[25]}\right)$ find that countries using macroprudential tools experience somewhat stronger and less volatile growth.

16. Measuring the cross-country intensity of macroprudential policy settings is challenging. Most existing databases usually rely on dummy or indicator variables for loosening ( $(-1)$, tightening $(+1)$, or no changes $(0)$ in LTV limits. However, using a dummy variable implies that changes of different magnitudes are treated equally. To provide a more precise measurement, this study uses the ECB Macroprudential Policies Evaluation Database (MaPPED) which offers a detailed overview of the evolution of macro- and microprudential policy instruments for $28 \mathrm{EU}$ member states with 1700 policy actions (e.g. implementation, recalibration or termination of an instrument) between 1995-2015 (Budnik and Kleibl, 2018 $\left.8_{[26]}\right)$. The ECB collected qualitative data by sending out open-text questionnaires to regulatory authorities of EU member states asking for the existence of macroprudential policy instruments and changes from 1995-2015. In order to allow the quantification of changes in levels of macroprudential policies across a large set of euro area countries, this paper translated qualitative responses of policy changes from the survey into quantitative measures. This study complements this information with data collected by the Secretariat. The use of official publications and policy notes of national central banks and supervisory authorities has allowed to increase the coverage of the dataset and to include non-European OECD member countries and key non-member economies (Brazil, Russia, India, Indonesia, China and South Africa).

17. This study also uses information on capital requirements. To do so, it relies on the MaPPED database, which provides detailed information of tightening or loosening of capital requirements and minimum Tier 1 ratios for the euro area, which is important when jointly examining the impact of risk weights and capital requirements. Information on capital requirements is complemented using the Bank Regulation and Supervision (BRSS) database of the World Bank. Cross-country coverage on minimum capital requirement in the dataset is extensive including non-euro area OECD countries. However, these data are 
only available for 2008,2009 and $2010 .^{3}$ Information on Tier 1 capital is not available in the BRSS and is complemented whenever possible with official regulatory data sources provided by the OECD country desks. For the purpose of the study, mortgage loan capital requirements are defined as the product of average risk weights for mortgage loans and the minimum Tier 1 ratio.

\subsubsection{Rental market regulation}

18. Rent controls, which have been introduced for a variety of social reasons, can also have implications for resilience (as well as important side effects on efficiency). Past OECD research has shown that excessively tight rent regulations can affect the supply of new dwellings and maintenance of the existing rental housing stock and hamper the development of the rental market (Caldera and Johansson, 2013 ${ }_{[27]}$ ). This in turn, can lead to shortages of housing supply, exacerbating speculative housing bubbles and increases in household debt posing significant vulnerabilities for macroeconomic stability and economic growth (Hermansen and Röhn, 2016[28]).

19. This study uses a new international longitudinal database of housing policies (i.e. rent control, tenure security and housing rationing) based on legislation and legal texts of 48 countries between 1910 and 2018 (Kholodilin, 2018 ${ }_{\text {[29] }}$ ) to quantify the degree of stringency of each of these policies. Legal acts are mapped into numeric values using variables that range from 1 , if regulation is stringent, to zero (if regulation is not stringent). Moreover, a summary index is constructed (called restrictive rental policy index) which simultaneously accounts for both rent control and protection from eviction. Using this database has important advantages: first, it covers a very long period of time, which is important, given long-lasting effects of housing regulations upon markets. Second, it uses a large panel of OECD countries. ${ }^{4}$ Using panel data allows accounting for unobservable country-specific effects.

\subsubsection{Property taxation}

20. Stamp duties should slow down house price booms by reducing the expected return on speculative house purchases. Higher stamp duties could thus reduce housing transaction volumes (Davidoff and Leigh, 2013 [30] $)$.

21. By contrast, recurring property taxes can be expected to have some stabilising effect on house prices, as long as they move in line with prices (van den Noord, $2005_{[31]}$ ). There is indeed some empirical evidence that higher recurring property taxes reduce house price volatility (Blöchliger, 2015 ${ }_{[32]}$ ).

22. New OECD measures allow gauging the combined weight of all tax instruments with relevance for housing, including personal income taxation, through marginal effective tax rates (METR) on owner-occupied and rental housing (OECD, 2018 [33]). The METRs are derived as the difference between the pre and post-tax rates of return of a marginal investment divided by the pre-tax rate of return of that investment where the post-tax real rate is the minimum rate of return necessary to make the investment worthwhile. METRs are calculated for several saving vehicles including owner-occupied and rental property.

3. Information for 2010 is extended until the introduction of Basel III in 2014 as there were few regulatory changes in between.

4. The database focuses mainly on national level regulations and not on the state or municipal level. 
Taxation of owner-occupied properties is typically lower as imputed rents are often not taxed and interest payments deductible. For the supply of housing, both types of investment matter.

\subsubsection{Public support for housing}

23. The public provision of social housing should in principle contribute to economic and especially social resilience (Salvi del Pero et al., 2016[34]). One channel with implications for resilience is that the availability of social housing reduces the need for more vulnerable and low-income workers to take risky housing loans in order to buy a home. Past OECD work has highlighted that low-income workers are more exposed than others to job-loss risk (Garda, 2016[35]).

24. The OECD Affordable Housing Database provides several indicators to measure the extent of public support for housing-related expenses. Two indicators are used for the purpose of this study: i) government support for social rental housing and ii) public spending on housing allowances.

\subsubsection{Land use policies}

25. Land use restrictions, which limit the freedom to build dwellings on new land or to densify existing built areas, have implications for housing cycles and economic resilience. Tight policies, which make building less responsive to demand, imply larger price swings but smaller construction swings (Glaeser and Gyourko, 2018 ${ }_{[36]}$ ). Both price and construction booms can contribute to the business and financial cycle and to the risk of damaging crises. The effect of land-use restrictions on economic resilience therefore remains an open question. Land use regulations are complex and quantitative indicators not readily available. Recent OECD work has produced several indicators for urban sprawl for most OECD countries (OECD, 2018 $[37])$. These indicators can be used to derive composite indicators for urban sprawl (Annex D).

\section{Housing policies and ex-ante resilience}

26. This section extends previous OECD work by estimating the impact of more and new housing-related and macroprudential policies on two measures of ex ante resilience, that is to say vulnerability (i.e. GDP-at-risk and severe downturns). This is the first study that analyses the long-term impact of rent regulation and tenure security separately in a macroeconomic framework.

\subsection{How do housing policies affect GDP-at-risk?}

27. Macroprudential and housing policies can affect the expected growth distribution. However, macroeconomic estimates predominantly focus on the expected mean growth, and usually do not model higher moments of the growth distribution. This focus on average growth can be too narrow when volatility and vulnerability increase as growth weakens, and may lead to the systematic underestimation of downside tail risks.

28. In the first part of this exercise, this study estimates the distribution of quarter-onquarter changes of output using a panel quantile regression model. The advantage of the method is that it allows the analysis of higher moments of the distribution and is robust to outliers. This exercise focuses on the median, the upper $95^{\text {th }}$ and the lower $5^{\text {th }}$ percentile of the distribution of quarter-on-quarter demeaned GDP growth, called GDP-at-risk and how macroprudential and housing market policies affects these outcomes. GDP-at-risk is the 
conditional growth of the (lower) $5^{\text {th }}$ percentile of the growth distribution and, thus captures expected growth at a low realisation of the GDP growth distribution. This study expands previous OECD work by Caldera Sánchez and Roehn (2016 [24] $)$ who use quantile regression estimations to investigate and quantify the impact of various policies (i.e. financial, labour market and external) on the distribution of quarter-on-quarter demeaned GDP growth.

29. The empirical analysis covers 34 advanced economies as well as 15 emerging market economies over the time period 1960-2016. The categorisation of emerging economies follows the classification by the IMF. ${ }^{5}$

\subsection{Estimation using quantile regressions and empirical results}

30. The quantile regression estimator was originally designed by Koenker and Bassett (1978) for the analysis of cross-sectional datasets. In a mean regression, panel data allow for the inclusion of fixed effects to control for unobserved country heterogeneity. Conditioning on individual fixed effects in quantile regressions is not straightforward. Quantile regression techniques suitable for panel data is still an active field of research and no preferred method has yet emerged from the literature as discussed in Caldera Sánchez and Roehn $\left(2016_{[24]}\right)$. Similar to Caldera Sánchez and Roehn $\left(2016_{[24]}\right)$, this study uses the two-step approach by Canay $\left(2011_{[38]}\right)$ in order to estimate quantile regressions with fixed effects. The panel quantile regression estimation takes the following form:

$$
Y_{i t}=X^{\prime}{ }_{i t} \beta_{\theta}+v_{i}+\mu_{i t} \text { with Quant }\left(Y_{i t} \mid X_{i t}\right)=x_{i t} \beta_{\theta}
$$

where $Y_{i t}$ is the quarter-on-quarter demeaned GDP growth rate for country $i$ at time $t . X^{\prime}{ }_{i t}$ is a vector of regressors including housing and macroprudential policies for country $i$ at time $t$ and a set of control variables ${ }^{6}$ that affect growth, $\beta$ is the vector of parameters to be estimated, and $\mu_{i t}$ is a vector of residuals. Quant $_{\theta}\left(Y_{i t} / X_{i t}\right)$ identifies the $\theta$ th conditional quantile of $Y$ given $X$. Canay's panel quantile regression estimator deals with the problem of estimating the fixed effects $v_{i}$ by assuming that they are 'pure location shift parameters' that take the same values at all values along the quantiles of the growth rate distribution.

31. Equation [1] estimates the impact of macroprudential and housing policies on vulnerability by looking at the quarter-to-quarter country demeaned growth distributions for all OECD and BRIICS countries and for advanced economies only. Timing and size of the detailed episodes of demeaned $5^{\text {th }}$ percentile growth rate are listed in Sakha (2019, forthcoming $\left.{ }_{[2]}\right)$. Time periods include the 1970s, 1980s, 1990s and 2000s. Summary statistics of the main policy variables can be found in Annex D. The regressions do not include time fixed effects as it is of interest to capture common shocks (e.g. financial crisis) on countries and their impact on the growth distribution. ${ }^{7}$ This approach is in line with the study of Caldera Sánchez and Roehn (2016[24]) as well Adrian et al. (2018[39]).

32. A challenge for empirical analysis of macroprudential tools is that their use was limited before the recent crisis, which limits the amount of data available for identification:

\section{5. https://www.imf.org/external/pubs/ft/weo/2018/02/weodata/groups.htm.}

6. The control variables include initial GDP per capita, trade openness, which is measured as exports plus imports as a share of GDP, government revenues as share of GDP, the real short-term interest rate and a financial openness index (defined as the ratio of private credit to GDP or stock market capitalization to GDP).

7. A disadvantage of this second approach, like in the standard within transformation, is that time invariant or slow moving policy variables cannot be investigated. 
this suggests that effects at this stage are estimated with a certain degree of tentativeness, before future evaluation exercises can provide firmer conclusions with the benefit of greater hindsight. Limited experience so far also precludes the empirical analysis of a potentially important question related to the effectiveness of actively moving LTV ceilings and capital requirements over the cycle.

33. Another factor complicating the analysis of their effects is that macroprudential measures have typically been taken not in isolation, but in combination with other policies, especially monetary policy. All regressions therefore include interest rates as a way (albeit imperfect) of capturing effects of monetary policy.

34. Table 3 provides the main results of the quantile regression analysis. ${ }^{8}$ The LTV cap variable is included separately in the regression while risk weights and minimum capital Tier 1 ratio are included jointly to determine the effect of risk weights and minimum capital requirement on economic growth. A loosening of LTV caps over time ${ }^{9}$ is positively correlated at the $50^{\text {th }}$ and $95^{\text {th }}$ percentile of the conditional GDP growth distribution suggesting that higher LTV caps are linked with stronger median and top growth.

35. Another set of regressions explore the links between risk weights and capital requirements (measured by the minimum Tier I ratio) and growth outcomes. They investigate the link by controlling for the two variables simultaneously which allows distinguishing between their respective impacts. Increases in risk weights for residential mortgages turn out to be positively associated with growth at the 95th percentile of the conditional GDP growth distribution. This result could reflect that tighter risk weights on more risky mortgages (which is what the risk-weight variable entering the regression measures) encourage banks to shift their lending portfolios away from high-risk mortgages funding purchases of houses (an asset with comparatively low-economic returns) towards more productive activities, leading to positive growth spurts. By contrast, the Tier 1 capital ratio is negatively associated with median growth. However, the minimum capital Tier 1 capital ratio became binding after the financial crisis, so that its effects are identified only during a fairly specific crisis and end-of-recovery period. In order to investigate long-term implications of changes in minimum capital Tier 1 capital ratio, a longer time interval would be needed.

8. Identifying causal effects from policies to growth is difficult given reverse causality and the lack of suitable instruments. Hence, results should not be interpreted in a causal way. However, interesting correlations may be discovered that should stimulate further research into causal relationships.

9. Formal lag selection procedures (AIC, BIC, and likelihood ratio tests) suggest to take three lags of LTV caps, risk weights and Tier 1 capital. 
Table 3. Macroprudential policies and GDP growth quantile regression

\begin{tabular}{lccccc}
\hline Panel A: All countries & \multicolumn{5}{c}{} \\
\hline & Q5 & Demeaned growth rate & Q50 & OLS & N \\
\hline LTV caps & -0.005 & $0.018^{* * *}$ & $0.023^{* * *}$ & 0.013 & 948 \\
& $(0.049)$ & $(0.004)$ & $(0.006)$ & $(0.012)$ & \\
Risk weights & -0.009 & 0.0002 & $0.011^{*}$ & -0.016 & 1309 \\
& $(0.009)$ & $(0.002)$ & $(0.007)$ & $(0.010)$ & \\
Minimum Tier 1 capital ratios & 0.009 & $-0.055^{*}$ & -0.029 & 0.072 & 1309 \\
& $(0.152)$ & $(0.028)$ & $(0.127)$ & $(0.131)$ & \\
\hline Panel B: Advanced countries & & & & & \\
\hline & & & & & \\
LTV caps & -0.002 & $0.019^{* * *}$ & $0.023^{* * *}$ & 0.011 & 836 \\
& $(0.036)$ & $(0.004)$ & $(0.006)$ & $(0.013)$ & \\
Risk weights & -0.022 & -0.001 & $0.016^{*}$ & 0.011 & 1197 \\
& $(0.014)$ & $(0.002)$ & $(0.008)$ & $(0.013)$ & \\
Minimum Tier 1 capital ratios & -0.203 & -0.051 & -0.0003 & -0.019 & 1197 \\
& $(0.169)$ & $(0.042)$ & $(0.155)$ & $(0.015)$ & \\
\hline Controls & Yes & Yes & Yes & Yes & \\
Country fixed effects & Yes & Yes & Yes & Yes & \\
Time fixed effects & No & No & No & Yes & \\
\hline
\end{tabular}

Note: Bootstrapped standard errors are reported in parentheses. $* * * \mathrm{p}<0.01,{ }^{* *} \mathrm{p}<0.05, * \mathrm{p}<0.1$. Control variables include initial log GDP per capita, trade openness measured as exports plus imports as a ratio of GDP, government revenues as a ratio of GDP, the real short-term interest rate and financial openness (defined as the ratio of private credit to GDP or stock market capitalization to GDP). Risk weights denotes the unweighted average of risk weights for LTVs ranging from 50 to 125. Risk weights are lagged by three quarters. LTV caps refer to caps on mortgage loans for the purchase of the primary residence. LTV caps are lagged by three quarters. Minimum Tier 1 capital is the bank's core capital that includes equity capital and disclosed reserves. Source: ECB Macroprudential Policies Evaluation Database (Budnik and Kleibl, 2018[26]), OECD, own calculations.

36. The results reported in Table 5 suggest that restrictive rental regulation makes the conditional growth distribution narrower with thinner tails on the lower and upper quantile. This points to a trade-off between GDP-at-risk at the lowest and highest quantiles indicating that regulation is there to strike a balance between various objectives. Looking at the restrictive regulation index, the coefficients at the lowest quantile are positively significant while negatively significant for the upper quantile. The positive effect holds for the tenure security index. One interpretation is that in countries with more restrictive housing market regulations, low-income households are better able to smooth income and consumption thanks to the stability provided by rent control and the reduced risk of eviction and homelessness through stronger tenure security. This narrowing of growth outcomes by restrictive rental market regulations does, however, not provide a protective form of stability, as it does not reduce the likelihood of long lasting severe downturns.

10. Excludes Russia, Lithuania and Poland. There is limited or no information available on macroprudential policies for other emerging economies such as Argentina, Brazil, Colombia, Chile, Mexico, India, Indonesia and South Africa (following the IMF classification of emerging economies. 
Table 4. Housing market policies and GDP growth quantile regression

\begin{tabular}{lccccc}
\hline Panel A: All countries & \multicolumn{5}{c}{ Demeaned growth rate } \\
\hline & $(1)$ & $(2)$ & $(3)$ & $(4)$ & N \\
\hline & Q5 & Q50 & Q95 & OLS & N \\
\hline Rental regulation index & $1.062^{* *}$ & $0.199^{*}$ & $-1.502^{* * *}$ & 0.529 & 1583 \\
& $(0.515)$ & $(0.111)$ & $(0.357)$ & $(0.77)$ & \\
Tenure security index & $0.753^{* *}$ & 0.046 & $-0.975^{* * *}$ & 0.451 & 1583 \\
& $(0.329)$ & $(0.069)$ & $(0.247)$ & $(0.60)$ & \\
Rent control index & 0.750 & $0.224^{*}$ & $-0.685^{*}$ & 0.240 & 1583 \\
& $(0.499)$ & $(0.125)$ & $(0.382)$ & $(0.59)$ & \\
Panel B: Advanced countries & & & & & \\
\hline Rental regulation index & $1.164^{* *}$ & 0.124 & $-1.992^{* * *}$ & 0.994 & 1445 \\
& $(0.515)$ & $(0.137)$ & $(0.305)$ & $(0.765)$ & \\
Tenure security index & $0.734^{* *}$ & 0.053 & $-1.157^{* * *}$ & -0.060 & 1445 \\
& $(0.338)$ & $(0.086)$ & $(0.227)$ & $(0.742)$ & \\
Rent control index & 0.770 & 0.155 & $-1.479^{* * *}$ & 0.632 & 1445 \\
& $(0.595)$ & $(0.142)$ & $(0.331)$ & $(0.424)$ & \\
\hline Control variables & Yes & Yes & Yes & Yes & \\
Country fixed effects & Yes & Yes & Yes & Yes & \\
Time fixed effects & No & No & No & Yes & \\
\hline
\end{tabular}

Note: Bootstrapped standard errors are reported in parentheses. *** $\mathrm{p}<0.01, * * \mathrm{p}<0.05, * \mathrm{p}<0.1$. Control variables include initial log GDP per capita, trade openness measured as exports plus imports as a ratio of GDP, government revenues as a ratio of GDP, the real short-term interest rate and financial openness (defined as the ratio of private credit to GDP or stock market capitalization to GDP). The rental regulation index is the simple average of the variables rent control and tenure security. The tenure security index is a variable that goes from 0 to 1 , the higher the value the more stringent the regulation based on four tenure security categories (i.e. eviction protection during term or period, eviction protection at the end of term or period, minimum duration variable, short-term tenancies). The rent control index is a variable that goes from 0 to 1 , the higher the value the more stringent the regulation based on six binary variables (i.e. real rent freeze, nominal rent freeze, rent level control, intertenancy control, other specific rent control). All housing policy variables are lagged by eight quarters.

Source: OECD Economic Outlook database and OECD calculations and DIW (Kholodilin, 2018[29]). 
37. By contrast the coefficients on the top quantiles are all negative and significant suggesting that tighter housing regulation is associated with fewer and weaker strong growth episodes. The results would be consistent with the empirical evidence that tight regulation affects the efficient reallocation of labour by hampering the migration of lowskilled workers towards high-income places and thereby productivity growth especially after an economic crisis (Andrews, Caldera Sánchez and Johansson, 2011 $1_{[3]}$ ). Empirical evidence by Charles, Notowidigdo and Hurst $\left(2018_{[40]}\right)$, and Gopinath $\left(2017_{[41]}\right)$ suggests that debt booms caused by house price fluctuations may reduce human capital accumulation and distort resource allocation in such a manner that it reduces longer-run output. The results are robust to changes in the lag structure and the specification of the quantile regressions.

\subsection{Estimation using a probabilistic model of a severe downturn and empirical results}

38. The analysis in this section investigates whether macroprudential and housing policies can mitigate or amplify severe downturns. It relies on the definition of severe downturns proposed by Turner, Chalaux and Morgavi (2018 $\left.{ }_{[42]}\right)$. A downturn is defined as a cumulative decline in real GDP per capita by at least 2 percentage points, the start being the first quarter where the real GDP per capita quarter-on-quarter growth is negative. The end of the episode is defined either when the quarter-on-quarter real GDP per capita returns back to at least to its previous level or when there are three consecutive positive quarteron-quarter growth rates. In the latter case, the downturn would stop at the first quarter of positive growth rates (see Turner, Chalaux and Morgavi, 2018).

39. The specification uses a probabilistic model of a severe downturn event in country $i$, in year $t$, as a function of lagged macroprudential and housing policies $P O L$ at year $t$ :

$$
\text { Probit }\left(p_{i t}\right)=\beta_{1}(\mathrm{~L}) P O L_{i t}+\gamma X_{i t}+\delta_{i}+\varepsilon_{i t}
$$

40. The dependent variable in the probit estimation is a dummy equal to one when there is a severe downturn episode and otherwise zero. The estimation includes the same control variables as used in the GDP-at-risk regressions.

41. Table 5 presents the results from the probit estimation. All specifications include country fixed effects. The main variable of interest is the sum of all lags of the policy variable. It is not possible to implement a probit model with year time effects due to the incidental parameters problem with small $\mathrm{T}$ and large $\mathrm{N}$ leading to inconsistent fixed effects estimators. Moreover, conditional fixed effects can only be estimated using years in the panel where there is variation in the outcome variable. Moreover, including time fixed effects removes time-varying common shocks which are captured in the severe downturn indicator. Accordingly, the probit model includes country but not time effects.

42. The key finding is that all estimates show that higher LTV caps, over the previous three quarters, are associated with a heightened risk of a severe downturn. The sum of the lag coefficients is statistically significant at the $5 \%$ confidence level. The diagnostic tests show that the three lags are jointly statistically significant at the $1 \%$ level.

43. No effect for the risk weights controlling for the level of minimum regulatory capital Tier 1 ratio was found. Looking at the minimum regulatory tier 1 ratio, this study finds that it is negatively associated with the risk of a downturn at the 10 and 5\% significance level. 
Table 5. Macroprudential policies and severe downturns

\begin{tabular}{|c|c|c|}
\hline & (1) & $(2)$ \\
\hline & Downturn & Downturn \\
\hline & & Advanced \\
\hline Sum of lagged coefficients, LTV caps & $0.026^{\star *}$ & $0.025^{\star *}$ \\
\hline S.E of sum of lagged coefficients & $(0.013)$ & $(0.013)$ \\
\hline Sum of lagged coefficients, risk weights & 0.014 & 0.011 \\
\hline S.E of sum of lagged coefficients & $(0.018)$ & $(0.020)$ \\
\hline Sum of lagged coefficients, Tier 1 & $-0.305^{*}$ & $-0.284^{\star *}$ \\
\hline S.E of sum of lagged coefficients & $(0.144)$ & $(0.143)$ \\
\hline Control variables & Yes & Yes \\
\hline Country fixed effects & Yes & Yes \\
\hline Observations & 1167 & 1101 \\
\hline
\end{tabular}

Note: Clustered standard errors are in parentheses; $* * * p<0.01, * * p<0.05, * p<0.1 . \quad$ The dependent variable takes the value of 1 if the real GDP per capita of a country falls cumulatively by at least 2 percentage points until quarter-on-quarter real GDP per capita goes back to at least its previous level or when there are three consecutive positive quarter-on-quarter growth episodes. In that case, the downturn would stop at the first quarter of positive growth. Control variables include initial log GDP per capita, trade openness measured as exports plus imports as a share of GDP, government revenues as share of GDP, the real short-term interest rate and financial openness (defined as the ratio of private credit to GDP or stock market capitalization to GDP).

Source: ECB Macroprudential Policies Evaluation Database (Budnik and Kleibl, 2018[26]), OECD, own calculations

44. The regression of rental regulation on the likelihood of severe downturns (Table 6) shows that the risk of a severe downturn is significantly exacerbated when rental regulation is tighter. This effect seems to be driven mostly by tenure security. ${ }^{11}$

Table 6. Rental regulation policies and severe downturns

\begin{tabular}{|c|c|c|}
\hline & $(1)$ & $(2)$ \\
\hline & Downturn & Downturn \\
\hline & & Advanced \\
\hline Sum of lagged coefficients, rental regulation index & $2.687^{\star *}$ & $4.032^{* * *}$ \\
\hline S.E of sum of lagged coefficients & $(1.378)$ & $(1.291)$ \\
\hline Sum of lagged coefficients, rent control & -0.075 & -0.126 \\
\hline S.E of sum of lagged coefficients & $(0.846)$ & $(1.857)$ \\
\hline Sum of lagged coefficients, tenure security & $2.472^{* \star *}$ & $2.705^{\star * *}$ \\
\hline S.E of sum of lagged coefficients & $(0.701)$ & $(0.779)$ \\
\hline Control variables & Yes & Yes \\
\hline Country fixed effects & Yes & Yes \\
\hline Observations & 1466 & 1374 \\
\hline
\end{tabular}

Note: Clustered standard errors are in parentheses; $* * * \mathrm{p}<0.01, * * \mathrm{p}<0.05, * \mathrm{p}<0.1$. The dependent variable takes the value of 1 if the real GDP per capita of a country falls cumulatively by at least 2 percentage points until quarter-on-quarter real GDP per capita goes back to at least to its previous level or when there are three

11. Regression estimates were also run using a "shock" as the dependent variable that takes the value of one if real per capita growth falls by 1 percentage point below potential in one quarter. The results are qualitatively similar. 
consecutive positive quarter-on-quarter growth rates. In that case, the downturn would stop at the first quarter of positive growth episodes. Control variables include initial log GDP per capita, trade openness measured as exports plus imports as a share of GDP, government revenues as share of GDP, the real short-term interest rate and financial openness (defined as the ratio of private credit to GDP or stock market capitalization to GDP).

Source: Kholodilin (2018[29]), OECD calculations.

\subsection{Robustness checks}

45. In the first robustness exercise, this paper takes a broader look at crisis episodes and looks at the lower $10^{\text {th }}$ percentile of quarter-on-quarter demeaned GDP growth rate. The results remain qualitatively the same. The results do not show any significant relationship between macroprudential policies such as LTV caps and risk weights controlling for minimum capital Tier 1 ratios at the lower quarter-on-quarter demeaned GDP growth distribution. For the rental regulation variables, the robustness exercise shows that more restrictive policies, especially tenure security, is associated with GDP-at-risk at the $10^{\text {th }}$ percentile of quarter-on-quarter demeaned GDP growth rate.

46. In the next exercise, this paper investigates whether previous findings hold using different lag structures. For macroprudential policies, this paper uses 5 lags (from previously used 3 lags). For the rental regulation index, it uses 6 lags (from previously used 8 lags). Positive coefficients on the maximum LTV ratios on the medium and upper tail growth distribution remain robust to different lag structures. This study also finds that results for the rental regulation policies remain robust to different lags structure.

47. Finally, further robustness tests include the employment of logistic regressions instead of probit for the analysis on severe downturns. The results remain significant. Detailed results of the robustness exercises are available in Sakha (2019, forthcoming $\left.{ }_{[2]}\right)$.

\section{Housing policies and ex-post resilience}

\subsection{How do housing policies affect the severity of downturns?}

48. To empirically assess the link between housing-related policies and resilience, resilience indicators are computed over all cycles (see Table 2 and Annex B). 4.3. Annex $\mathrm{G}$ reports standardised coefficients (t-stats) of the corresponding pooled univariate regressions. The results suggest that tighter LTV caps are associated with lower amplitudes of real output cycles. But tighter LTV caps also significantly weaken the strength of the recovery of business cycles and, to a lesser extent, of deviation cycles.

49. More stringent tenure security is associated with shorter and less pronounced output booms and also less severe downturns hinting at more stable financial conditions for households which allows for smoother consumptions paths. Similarly, more generous housing allowances tend to shorten and smoothen output cycles. As a result, pre-crisis levels of output are reached significantly faster.

50. Marginal effective tax rates on housing property are only available for the most recent period. As they generally do not change much over time, cross-country differences are assumed to be stable over time. Extrapolation of tax rates allows to assess their impact 
on the cross-section. Tentative results suggest that property tax rates are associated with a lower amplitude of real cycles, in particular in the case of rental income.

51. Proxies for building restrictions suggest a link between tighter restrictions and more moderate housing price busts as well as faster recoveries of residential investment. This association is likely to reflect that building restrictions limit the scope for overbuilding, even if they may have other adverse implications.

\subsection{How do policies affect the transmission of housing shocks?}

52. To shed light on the transmission of housing shocks, turning points of real house price cycles are identified. The subsequent correction of house prices is used as a proxy for adverse housing shocks. The stance of various housing-related policies is observed at the peak of the house price cycles and compared to the growth of real house prices, housing investment, household credit and private consumption following the peak in house prices during the subsequent two years. Table 7 summarises the results.

53. Stricter capital requirements limit the correction of both house prices and housing investment which seems to support private consumption. Tighter LTV caps slow down household credit and hold back its recovery, but do not seem to have significant effects on housing outcomes or consumption following a correction of house prices. More stringent rent control seems to exacerbate house price corrections. It is also associated with stronger growth in household credit which may be related to lower counter-party risk for banks resulting in more stable bank lending to households. 
Table 7. How do housing policies affect the transmission of house price corrections?

\begin{tabular}{lcccc}
\hline & $\begin{array}{c}\text { Real house } \\
\text { prices }\end{array}$ & $\begin{array}{c}\text { Housing } \\
\text { investment }\end{array}$ & $\begin{array}{c}\text { Household } \\
\text { credit }\end{array}$ & $\begin{array}{c}\text { Private } \\
\text { consumption }\end{array}$ \\
\hline $\begin{array}{l}\text { Capital } \\
\text { requirements }\end{array}$ & $\left(0.098^{* *}\right.$ & $0.224^{* *}$ & -0.039 & $0.037^{*}$ \\
& -0.002 & $(0.091)$ & $(0.032)$ & $(0.021)$ \\
LTV caps & $(0.004)$ & -0.002 & $0.005^{* * *}$ & 0.001 \\
& $(0.008)$ & $(0.001)$ & $(0.002)$ \\
Rent control & $-0.092^{*}$ & -0.063 & $0.213^{* * *}$ & 0.005 \\
& $(0.052)$ & $(0.113)$ & $(0.069)$ & $(0.026)$ \\
Tenure security & $(0.074)$ & $(0.100)$ & $(0.055)$ & $(0.023)$ \\
\hline
\end{tabular}

Note: Turning points of real house prices are obtained using the Harding-Pagan (quarterly Bry-Boschan) business cycle dating procedure (Harding and Pagan, 2002[4]). The subsequent 2-year growth of outcome variables (columns) are pooled and regressed on time-varying policy variables (rows). The table displays regression coefficients. Standard deviations are in parentheses and stars denote statistical confidence levels: ${ }^{*} \mathrm{p}<0.1 ; * * \mathrm{p}<0.05 ; * * * \mathrm{p}<0.01$.

\subsection{Gauging causality: Measuring the impact of policy changes on real, financial and housing variables}

54. In an attempt to alleviate concerns about endogeneity and reverse causality, this section assesses the impact of a policy change on real, financial and housing variables using matching techniques. The idea is to simulate a natural experiment by comparing two episodes that are as similar as possible, one with a policy change (treatment) and one without (control). The policy change can then by assumed to be exogenous and observed outcome differences between the treatment and the control group are likely to be caused by the policy change.

55. One matching technique is propensity matching. First, a treatment group consisting of countries with policy change events is identified. Second, a probit model with 1-year and 3-year changes of real, financial and housing-related variables as predictors of policy changes is built using stepwise selection. Based on the obtained functional relationship a control group is constructed by finding country-period pairings without a policy change but with similar statistical properties than the treatment country-period pairings. Local smoothing is then used to obtain an estimate of the average path of i) credit to households, ii) real house prices, iii) housing investment and iv) private consumption around the time of policy changes (in the case of the treatment group).

56. The results suggests that a tightening of LTV caps curbs credit to households, slows real house prices and construction while there is no sizeable impact on private consumption or aggregate output (Figure 5). 
Figure 5. Effect of tightening LTV caps
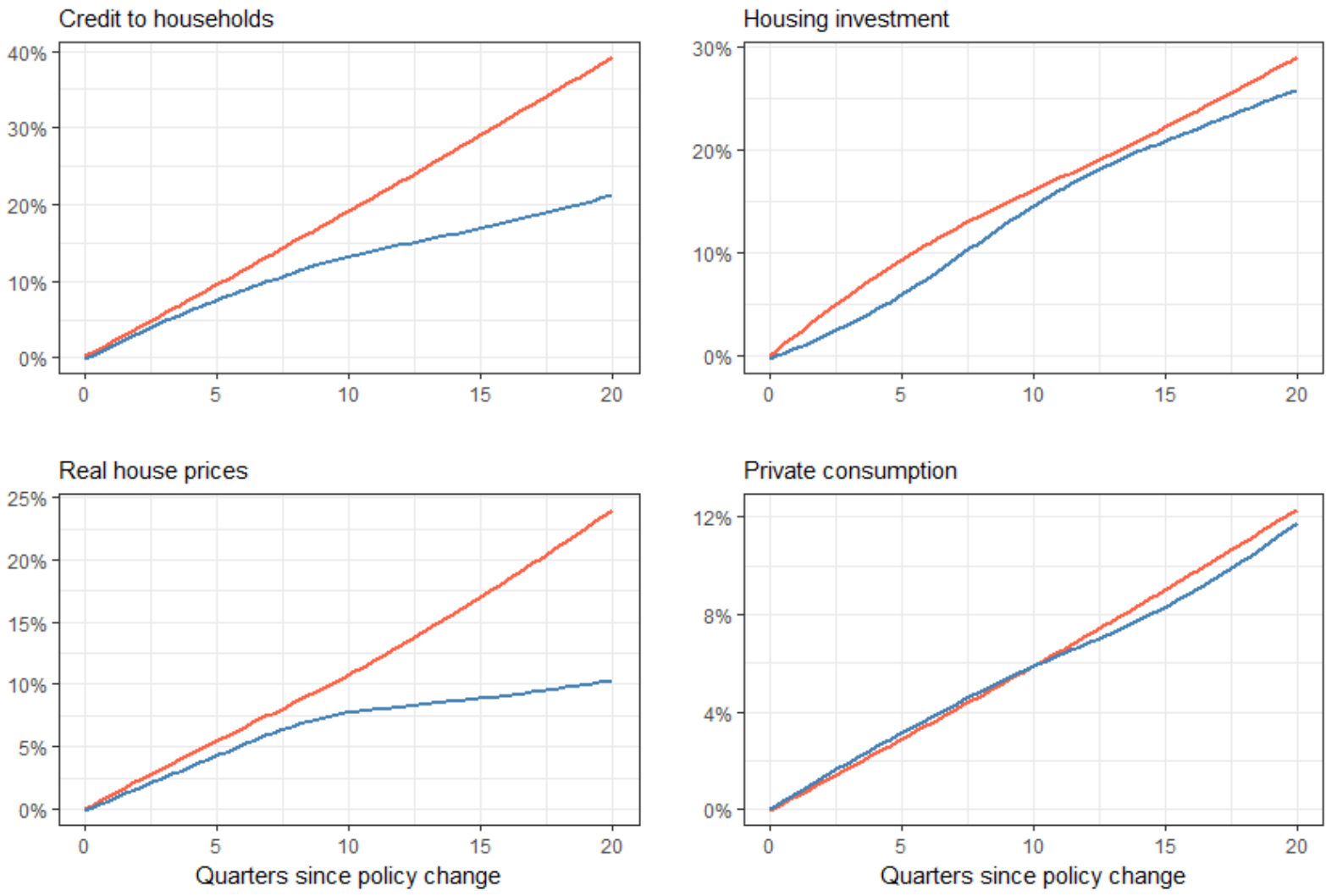

- No policy change - Tightening

Note: The treatment group consists of country-episodes with a tightening of LTV caps at time $=0$. The control group, comprising country-episode pairings without such a policy change, has been determined by propensity matching techniques using a probit model with real and financial variables as covariates.

Source: OECD calculations.

57. Increasing risk weights imposed on banks for their mortgage portfolio has similar effects on credit and house prices as tightening LTV caps (Figure 6). ${ }^{12}$ The effects are larger, primarily because many of the tightening actions fall in the period of the global financial crisis. The dampening effect on real house prices is more persistent than in the case of LTV caps and residential construction declines more strongly, which slows down both GDP and consumption compared with the control group.

12. Capital requirements are not introduced in this part of the analysis to avoid excessively shrinking the sample. 
Figure 6. Effect of tightening of risk weights
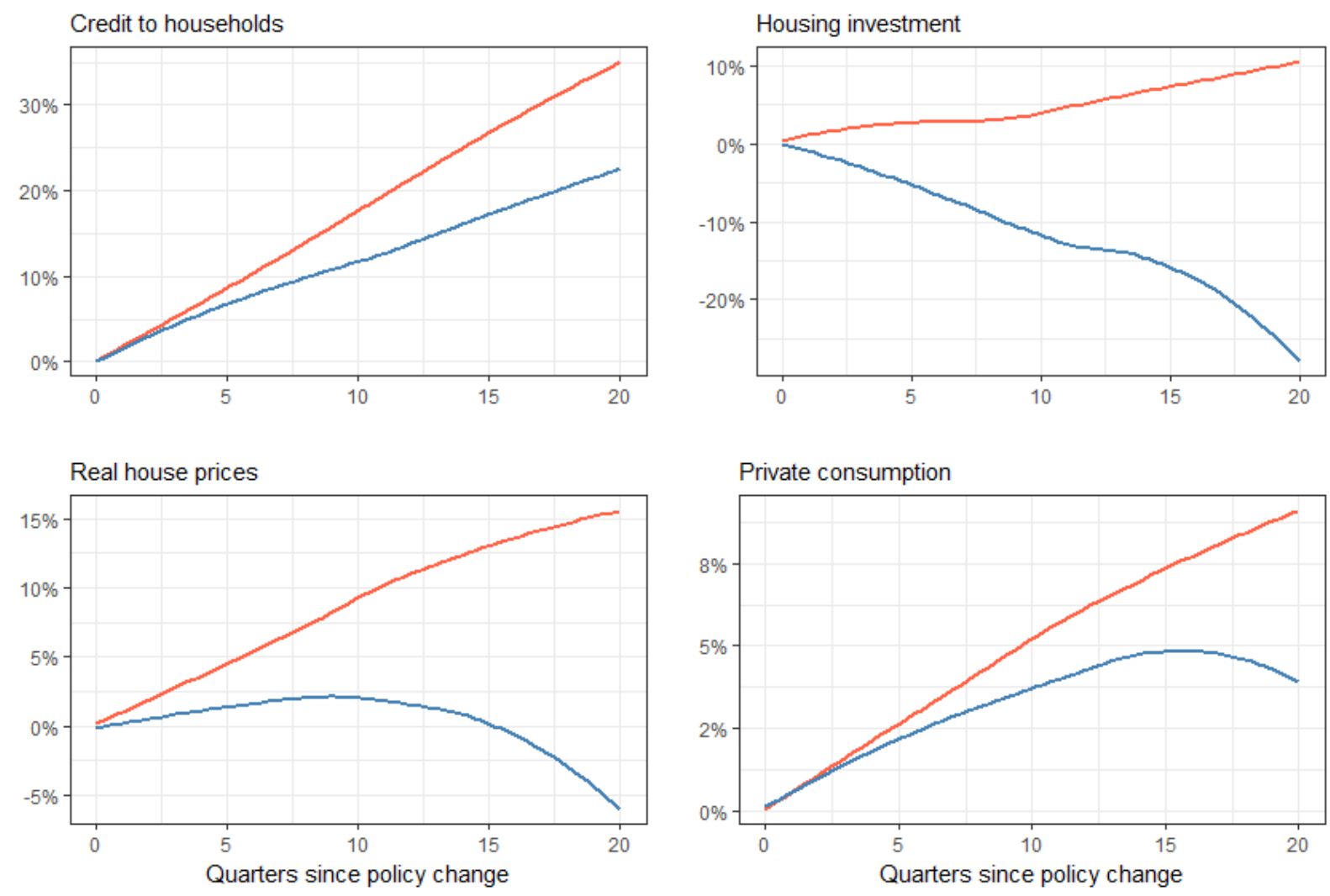

- No policy change — Tightening

Note: The treatment group consists of country-episodes with an increase of risk weights at time $=0$. The control group, comprising country-episode pairings without such a policy change, has been determined by propensity matching techniques using a probit model with real and financial variables as covariates.

Source: OECD calculations.

58. Propensity matching suggests that reducing rent control boosts both residential construction and house prices (Figure 7). Effects on aggregate output and private consumption are tiny suggesting that deregulation merely alters investment opportunities leading to a shift towards real estate away from other forms of investment. Deregulating rental markets increases expected returns from housing investment let out for rental. The resulting increase in housing supply boosts both residential investment and real house prices. 
Figure 7. Effect of loosening rent control
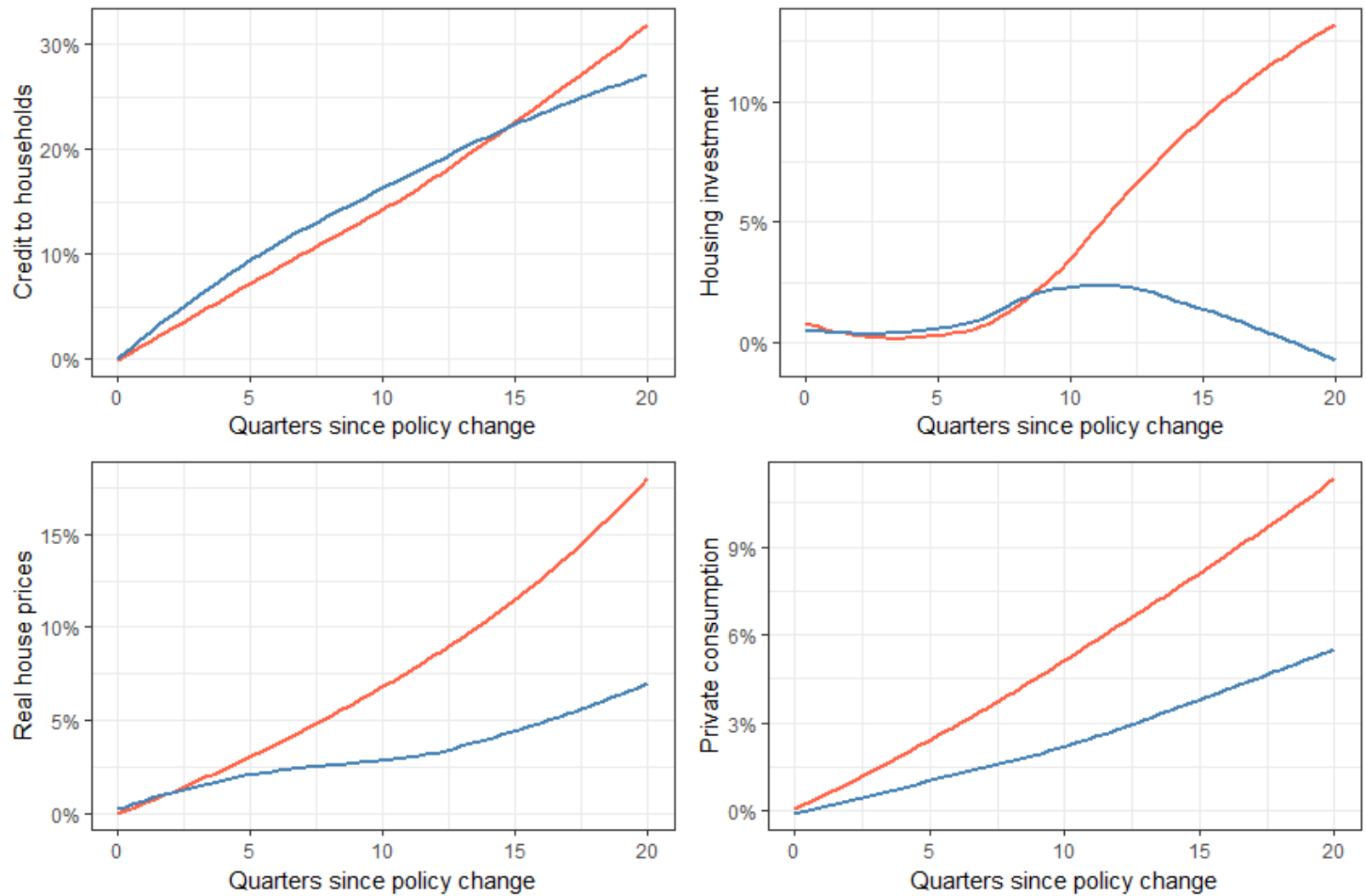

- Loosening - No policy change

Note: The treatment group consists of country-episodes with a loosening of rental regulation at time $=0$. The control group, comprising country-episode pairings without such a policy change, has been determined by propensity matching techniques using a probit model with real and financial variables as covariates. Source: OECD calculations 


\section{References}

Acharya, V., R. Engle and D. Pierre (2014), "Testing macroprudential stress tests: The risk of regulatory risk weights", Journal of Monetary Economics, Vol. 65, pp. 36-53.

Adalet McGowan, M. and D. Andrews (2015), "Labour Market Mismatch and Labour Productivity: Evidence from PIAAC Data", OECD Economics Department Working Papers, No. 1209, OECD Publishing, Paris, https://dx.doi.org/10.1787/5js1pzx1r2kb-en.

Adrian, T. et al. (2018), "The Term Structure of Growth-at-Risk", 18, No. 180, IMF Working Paper Series, https://www.imf.org/en/Publications/WP/Issues/2018/08/02/The-TermStructure-of-Growth-at-Risk-46150.

Aiyar, S., C. Calomiris and T. Wieladek (2014), "Does Macro-Prudential Regulation Leak? Evidence from a UK Policy Experiment", Journal of Money, Credit and Banking, Vol. 46/s1, pp. 181-214, http://dx.doi.org/10.1111/jmcb.12086.

Akgun, O., B. Cournède and J. Fournier (2017), "Effects of the Tax Mix on Inequality and Growth", OECD Economics Department Working Papers, OECD Publishing.

Alam, Z. et al. (2019), "Digging Deeper-Evidence on the Effects of Macroprudential Policies from a New Database IMF Working Paper Monetary and Capital Markets Department", IMF Working Paper, No. 19/66.

André, C. et al. (2018), "Can monetary policy lean against housing bubbles?", Department of Economics working paper series, No. 201877, University of Pretoria, Pretoria, http://dx.doi.org/Department of Economics Working Paper Series.

Andrews, D., A. Caldera Sánchez and Å. Johansson (2011), "Housing Markets and Structural Policies in OECD Countries", OECD Economics Department Working Papers, No. 836, OECD Publishing, Paris, https://dx.doi.org/10.1787/5kgk8t2k9vf3-en.

Armstrong, J., H. Skilling and F. Yao (2019), "Loan-to-value ratio restrictions and house prices: Micro evidence from New Zealand", Journal of Housing Economics, Vol. 44, pp. 88-98, http://dx.doi.org/10.1016/j.jhe.2019.02.002.

Balfoussia, H., H. Dellas and D. Papageorgiou (2018), "Loan-To-Value Ratio Limits: An Exploration for Greece", Working Paper, No. 248, Bank of Greece.

Baptista, R. et al. (2016), "Macroprudential policy in an agent-based model of the UK housing market", Working Paper, No. 619, Bank of England.

Barcelo, C. (2003), "Housing Tenure and Labour Mobility: A Comparison Across European Countries", Documentos de Trabajo, No. 0603, Banco de España, http://dx.doi.org/10.2139/ssrn.383520. 
Bednarek, P. et al. (2019), Capital Flows, Real Estate, and City Business Cycles: Micro Evidence from the German Boom, http://52.76.234.106/media/abfer-events-2019/annualconference/real-estate/AC19P6012_Capital_Flows_Real_Estate_and_City_Cycles.pdf.

BIS (2018), "Moving forward with macroprudential frameworks", in BIS Annual Economic Report.

Blöchliger, H. (2015), "Reforming the Tax on Immovable Property: Taking Care of the Unloved”, OECD Economics Department Working Papers, No. 1205, OECD Publishing, Paris, https://dx.doi.org/10.1787/5js30tw0n7kg-en.

Boar, C. et al. (2017), "What are the effects of macroprudential policies on macroeconomic performance?”, BIS Quarterly Review, https://www.bis.org/publ/qtrpdf/r_qt1709g.pdf.

Borio, C. (2014), The international monetary and financial system: its Achilles heel and what to do about it, http://www.bis.org.

Bruneau, G., I. Christensen and C. Meh (2018), "Housing market dynamics and macroprudential policies", Canadian Journal of Economics, http://dx.doi.org/10.1111/caje.12346.

Budnik, K. and J. Kleibl (2018), "Macroprudential regulation in the European Union in 19952014: introducing a new data set on policy actions of a macroprudential nature", Working Paper Series, No. 2123, European Central Bank, http://dx.doi.org/10.2866/875405.

Bulow, J. and P. Klemperer (2012), "Regulated Prices, Rent Seeking, and Consumer Surplus", Journal of Political Economy, Vol. 120/1, pp. 160-186, http://dx.doi.org/10.1086/665416.

Caldera Sánchez, A. et al. (2017), "Strengthening economic resilience: Insights from the post1970 record of severe recessions and financial crises", OECD Economic Policy Papers, No. 20, OECD Publishing, Paris, https://dx.doi.org/10.1787/6b748a4b-en.

Caldera Sánchez, A. and O. Röhn (2016), "How do policies influence GDP tail risks?”, OECD Economics Department Working Papers, No. 1336, OECD Publishing, Paris, http://www.oecd.org/eco/workingpapers.

Caldera, A. and Å. Johansson (2013), "The price responsiveness of housing supply in OECD countries", Journal of Housing Economics, Vol. 22/3, pp. 231-249, http://dx.doi.org/10.1016/J.JHE.2013.05.002.

Canay, I. (2011), "A simple approach to quantile regression for panel data", The Econometrics Journal, Vol. 14/3, pp. 368-386, http://dx.doi.org/10.1111/j.1368-423X.2011.00349.x.

Cavalleri, M., B. Cournède and V. Ziemann (2019), "Housing markets and macroeconomic risks", OECD Economics Department Working Papers, No. 1555, OECD Publishing, Paris, https://dx.doi.org/10.1787/737133d8-en.

Cerutti, E., S. Claessens and L. Laeven (2017), "The use and effectiveness of macroprudential policies: New evidence", Journal of Financial Stability, Vol. 28, pp. 203-224, http://dx.doi.org/10.1016/J.JFS.2015.10.004. 
Charles, K., E. Hurst and M. Notowidigdo (2018), "Housing Booms and Busts, Labor Market Opportunities, and College Attendance", American Economic Review, Vol. 108/10, pp. 29472994, http://dx.doi.org/10.1257/aer.20151604.

Claessens, S., S. Ghosh and R. Mihet (2013), "Macro-prudential policies to mitigate financial system vulnerabilities", Journal of International Money and Finance, Vol. 39, pp. 153-185, http://dx.doi.org/10.1016/J.JIMONFIN.2013.06.023.

Cournède, B., O. Denk and P. Hoeller (2015), "Finance and Inclusive Growth", OECD Economic Policy Papers, No. 14, OECD Publishing, Paris, https://dx.doi.org/10.1787/5js06pbhf28s-en.

Davidoff, I. and A. Leigh (2013), "How Do Stamp Duties Affect the Housing Market?", Economic Record, Vol. 89/286, pp. 396-410, http://dx.doi.org/10.1111/1475-4932.12056.

Davis, S. and J. Haltiwanger (2019), "Dynamism Diminished: The Role of Housing Markets and Credit Conditions", NBER Working Paper, Vol. 25466, http://dx.doi.org/10.3386/w25466.

Diamond, R., T. Mcquade and F. Qian (2018), "The Effects of Rent Control Expansion on Tenants, Landlords, and Inequality: Evidence from San Francisco", Journal of Political Economy, forthcoming, https://web.stanford.edu/ diamondr/DMQ.pdf.

Ferrero, A., R. Harrison and B. Nelson (2018), "Concerted efforts? Monetary policy and macroprudential tools", Staff Working Paper, No. 727, Bank of England, http://www.bankofengland.co.uk/working-paper/Working-papers.

Fissel, G., G. Hanweck and A. Sanders (2018), "Residential House Prices, Commercial Real Estate and Bank Failures", George Mason University School of Business Research Paper, No. 18-1, http://dx.doi.org/10.2139/ssrn.2995113.

Funke, M. and M. Paetz (2016), "Dynamic Stochastic General Equilbirum-Based Assessment of Nonlinear Macroprudential Policies: Evidence from Hong Kong", Pacific Economic Review, Vol. 23/4, pp. 632-657, http://dx.doi.org/10.1111/1468-0106.12170.

Gabarro, M. et al. (2019), "Macroprudential Policy and Household Leverage: Evidence from Administrative Household-Level Data", CEPR Discussion Paper, No. 13503.

Galati, G. and R. Moessner (2012), "Macroprudential Policy - A Literature Review", Journal of Economic Surveys, Vol. 27/5, pp. 846-878.

Garda, P. (2016), "The Ins and Outs of Employment in 25 OECD Countries", OECD Economics Department Working Papers, No. 1350, OECD Publishing, Paris, https://dx.doi.org/10.1787/3f9fa009-en.

Glaeser, E. and J. Gyourko (2018), “The Economic Implications of Housing Supply”, Journal of Economic Perspectives, http://dx.doi.org/10.1257/jep.32.1.3.

Glaeser, E. and E. Luttmer (2003), "The Misallocation of Housing Under Rent Control”, American Economic Review, Vol. 93/4, pp. 1027-1046, http://dx.doi.org/10.1257/000282803769206188. 
Goodman, L. and C. Mayer (2018), "Homeownership and the American Dream", Journal of Economic Perspectives, http://dx.doi.org/10.1257/jep.32.1.31.

Gopinath, G. et al. (2017), "Capital Allocation and Productivity in South Europe*", The Quarterly Journal of Economics, Vol. 132/4, pp. 1915-1967, http://dx.doi.org/10.1093/qje/qjx024.

Greenwald, D. (2018), "The Mortgage Channel of Macroeconomic Transmission”, mimeo.

Griffin, J., S. Kruger and G. Maturana (2018), "What Drove the 2003-2006 House Price Boom and Subsequent Collapse? Disentangling Competing Explanations *”, mimeo.

Gyourko, J. and P. Linneman (1989), "Equity and efficiency aspects of rent control: An empirical study of New York City", Journal of Urban Economics, Vol. 26/1, pp. 54-74, http://dx.doi.org/10.1016/0094-1190(89)90027-2.

Harding, D. and A. Pagan (2002), "Dissecting the cycle: a methodological investigation", Journal of Monetary Economics, Vol. 49/2, pp. 365-381, http://dx.doi.org/10.1016/S03043932(01)00108-8.

Hermansen, M. and O. Röhn (2016), "Economic resilience: The usefulness of early warning indicators in OECD countries", OECD Journal: Economic Studies, https://www.oecdilibrary.org/docserver/eco studies-20165jg2ppjrd6r3.pdf? expires $=1547983022 \&$ id $=$ id \&accname $=$ ocid $84004878 \&$ checksum $=3$ A 3 C6 140FEC597236FBC3673C21D5C42.

Hilber, C. and T. Lyytikäinen (2017), "Transfer taxes and household mobility: Distortion on the housing or labor market?", Journal of Urban Economics, http://dx.doi.org/10.1016/j.jue.2017.06.002.

Hsieh, C. and E. Moretti (2015), "Housing Constraints and Spatial Misallocation", NBER Working Papers 21154, http://www.nber.org/papers/w21154.

Jordà, Ò., M. Schularick and A. Taylor (2014), The Great Mortgaging: Housing Finance, Crises, and Business Cycles, National Bureau of Economic Research, Cambridge, MA, http://dx.doi.org/10.3386/w20501.

Kelly, R., F. McCann and C. O'Toole (2018), "Credit conditions, macroprudential policy and house prices", Journal of Housing Economics, http://dx.doi.org/10.1016/j.jhe.2018.05.005.

Kholodilin, K. (2018), "Measuring Stick-Style Housing Policies: A Multi-Country Longitudinal Database of Governmental Regulations", DIW Berlin Discussion Paper, No. 1727, http://dx.doi.org/10.2139/ssrn.3146755.

Kholodilin, K., A. Mense and C. Michelsen (2016), "Market Break or Simply Fake? Empirics on the Causal Eff ects of Rent Controls in Germany", No. 1584, DIW Working Paper Series, http://www.diw.de/discussionpapers (accessed on 16 January 2019). 
Kim, S. and A. Mehrotra (2018), "Effects of Monetary and Macroprudential Policies-Evidence from Four Inflation Targeting Economies", Journal of Money, Credit and Banking, Vol. 50/5, pp. 967-992, http://dx.doi.org/10.1111/jmcb.12495.

Kuncl, M. (2016), "Assessment of the Effects of Macroprudential Tightening in Canada", Staff Analytical Note, No. 2016-12, Bank of Canada, http://www.bank-banquecanada.caStaffAnalyticalNote/Noteanalytiquedupersonnel2016-12.

Laamanen, J. (2017), "Home-ownership and the Labour Market: Evidence from Rental Housing Market Deregulation", Labour Economics, Vol. 48, pp. 157-167, http://dx.doi.org/10.1016/j.labeco.2017.08.005.

Laliotis, D. and J. Población (2016), Agent Based Models for the Assessment of the Application LTV/LTI Cap Macroprudential Measures, https://editorialexpress.com/cgibin/conference/download.cgi?db_name=CEF2017\&paper_id=178.

Laufer, S. et al. (2018), "The Effect of LTV-Based Risk Weights on House Prices: Evidence from an Israeli Macroprudential Policy".

Lim, C. et al. (2011), "Macroprudential Policy: What Instruments and How to use Them?", IMF Working Paper Series, No. WP/11/238, IMF.

Lim, T. (2018), "Housing as collateral, financial constraints, and small businesses", Review of Economic Dynamics, Vol. 30, pp. 68-85, http://dx.doi.org/10.1016/j.red.2018.03.001.

Lux, M. and P. Sunega (2012), "Labour Mobility and Housing", Urban Studies, Vol. 49/3, pp. 489-504, http://dx.doi.org/10.1177/0042098011405693.

Metcalf, G. (2018), "Sand Castles Before the Tide? Affordable Housing in Expensive Cities", Journal of Economic Perspectives, Vol. 32/1, pp. 59-80, http://dx.doi.org/10.1257/jep.32.1.59.

Miles, W. (2019), “Home Prices and Global Imbalances: Which Drives Which?", Kyklos, Vol. 72/1, pp. 55-75, http://dx.doi.org/10.1111/kykl.12191.

Muellbauer, J. and A. Murphy (1997), "Booms and Busts in the UK Housing Market", The Economic Journal, Vol. 107/445, pp. 1701-1727, http://dx.doi.org/10.1111/j.14680297.1997.tb00076.x.

OECD (2018), Rethinking Urban Sprawl: Moving Towards Sustainable Cities, OECD Publishing, Paris, https://dx.doi.org/10.1787/9789264189881-en.

OECD (2018), Taxation of Household Savings, OECD Tax Policy Studies, No. 25, OECD Publishing, Paris, https://dx.doi.org/10.1787/9789264289536-en.

OECD (2017), “OECD Economic Outlook”, Vol. 2017/2, https://dx.doi.org/10.1787/eco_outlook-v2017-2-en.

OECD (2017), Resilience in a time of high debt, OECD Economic Outlook. 
OECD (2011), "Housing and the Economy: Policies for Renovation", in Economic Policy Reforms 2011: Going for Growth, OECD Publishing, Paris, https://dx.doi.org/10.1787/growth-2011-46-en.

Poghosyan, T. (2019), "How Effective is Macroprudential Policy? Evidence from Lending Restriction Measures in EU Countries", IMF Working Papers, No. 19/45, IMF, http://dx.doi.org/10.5089/9781498300872.001.

Richter, B., M. Schularick and I. Shim (2018), "The Costs of Macroprudential Policy", Journal of International Economics, forthcoming, https://www.nber.org/papers/w24989.pdf.

Rupert, P. and E. Wasmer (2012), "Housing and the labor market: Time to move and aggregate unemployment", Journal of Monetary Economics, Vol. 59/1, pp. 24-36, http://dx.doi.org/10.1016/j.jmoneco.2011.10.008.

Sakha, S. (2019, forthcoming), "Additional evidence on the links between housing policies and economic resilience", OECD Economics Department Working Papers.

Salvi del Pero, A. et al. (2016), "Policies to promote access to good-quality affordable housing in OECD countries", OECD Social, Employment and Migration Working Papers, No. 176, OECD Publishing, Paris, https://dx.doi.org/10.1787/5jm3p5gl4djd-en.

Turner, D. (2017), "Designing fan charts for GDP growth forecasts to better reflect downturn risks", OECD Economics Department Working Papers, No. 1428, OECD Publishing, Paris, https://dx.doi.org/10.1787/e86f1bfc-en.

Turner, D., T. Chalaux and H. Morgavi (2018), "Fan charts around GDP projections based on probit models of downturn risk", OECD Economics Derpartment Working Paper, No. 1521, OECD Publishing, Paris, http://www.oecd.org/eco/workingpapers.

van den Noord, P. (2005), "Tax Incentives and House Price Volatility in the Euro Area: Theory and Evidence", Economie Internationale 101, pp. 29-45, https://www.cairn.info/revueeconomie-internationale-2005-1-page-29.htm.

Webley, T. (2018), "Fundamental Drivers of Existing Home Sales in Canada", Staff Discussion Paper, No. 16, Bank of Canada, http://www.bank-banque-canada.ca.

Xiong, Q. and A. Mavropoulos (2018), "Housing Consumption and Macroprudential Policies in Europe: An Ex Ante Evaluation”, IWH Discussion Papers, No. 17/2018, http://www.iwhhalle.de. 
Annex A. Coverage of outcome variables

\begin{tabular}{|c|c|c|c|}
\hline & Real GDP & House prices & Housing investment \\
\hline ARG & 1993-2017 & & \\
\hline AUS & $1969-2017$ & $1970-2017$ & $1969-2017$ \\
\hline AUT & $1976-2017$ & $2000-2017$ & 1976-2017 \\
\hline BEL & $1969-2017$ & $1970-2017$ & $1969-2017$ \\
\hline BRA & $1980-2017$ & 2008-2017 & \\
\hline CAN & 1969-2017 & $1970-2017$ & $1969-2017$ \\
\hline CHE & 1991-2017 & $1991-2017$ & $1991-2016$ \\
\hline $\mathrm{CHL}$ & $1996-2017$ & $2002-2017$ & 1996-2014 \\
\hline $\mathrm{CHN}$ & $1990-2017$ & $2010-2017$ & \\
\hline $\mathrm{COL}$ & $2001-2017$ & 2001-2017 & 2001-2017 \\
\hline CRI & 1998-2017 & & \\
\hline CZE & $1996-2017$ & $2008-2017$ & 1996-2017 \\
\hline DEU & $1970-2017$ & $1970-2017$ & $1970-2017$ \\
\hline DNK & $1972-2017$ & $1972-2017$ & $1972-2017$ \\
\hline ESP & $1978-2017$ & $1978-2017$ & $1978-2017$ \\
\hline EST & $2000-2017$ & $2005-2017$ & $2000-2017$ \\
\hline FIN & $1970-2017$ & $1970-2017$ & $1970-2017$ \\
\hline FRA & $1979-2017$ & $1979-2017$ & $1980-2017$ \\
\hline GBR & $1971-2017$ & $1971-2017$ & $1971-2017$ \\
\hline GRC & $1984-2017$ & $1997-2017$ & $1984-2017$ \\
\hline HUN & $1995-2017$ & $2007-2017$ & $1995-2017$ \\
\hline IDN & $1990-2017$ & 2002-2017 & \\
\hline IND & $1997-2017$ & $2010-2017$ & \\
\hline IRL & $1977-2017$ & $1977-2017$ & $1977-2017$ \\
\hline ISL & $1970-2017$ & $2005-2017$ & $1970-2017$ \\
\hline ISR & $1995-2017$ & $1995-2017$ & $1995-2017$ \\
\hline ITA & $1969-2017$ & $1970-2017$ & $1969-2017$ \\
\hline JPN & $1972-2017$ & $1972-2017$ & $1972-2017$ \\
\hline KOR & $1975-2017$ & $1986-2017$ & $1975-2017$ \\
\hline LTU & 2002-2017 & $2006-2017$ & $2002-2017$ \\
\hline LUX & $1995-2017$ & 2007-2017 & $1995-2017$ \\
\hline LVA & $1996-2017$ & 2006-2017 & $1996-2017$ \\
\hline MEX & $1995-2017$ & $2005-2017$ & $1995-2017$ \\
\hline NLD & 1969-2017 & $1970-2017$ & 1969-2017 \\
\hline NOR & $1978-2017$ & $1978-2017$ & $1978-2017$ \\
\hline NZL & $1989-2017$ & $1989-2017$ & $1989-2017$ \\
\hline POL & $1995-2017$ & $2010-2017$ & $1995-2017$ \\
\hline PRT & $1980-2017$ & $1988-2017$ & $1980-2017$ \\
\hline RUS & 1999-2017 & $2001-2017$ & \\
\hline SVK & $1996-2017$ & $2005-2017$ & $1996-2017$ \\
\hline SVN & $1999-2017$ & $2007-2017$ & $1999-2017$ \\
\hline SWE & $1969-2017$ & $1970-2017$ & $1970-2017$ \\
\hline TUR & $1995-2017$ & $2010-2017$ & \\
\hline USA & $1969-2017$ & $1970-2017$ & $1969-2017$ \\
\hline ZAF & $2001-2017$ & 2001-2017 & 2001-2017 \\
\hline
\end{tabular}

Source: OECD Economic Outlook database and OECD Analytical House Price database. 


\section{Annex B. Resilience indicators}

Table B.1. Business cycles

\begin{tabular}{|c|c|c|c|c|c|c|c|c|c|}
\hline & $\begin{array}{l}\text { Downturn } \\
\text { probability }\end{array}$ & Q5 & $\begin{array}{l}\text { Volatility } \\
\text { (boom) }\end{array}$ & $\begin{array}{l}\text { Volatility } \\
\text { (bust) }\end{array}$ & $\begin{array}{l}\text { Duration } \\
\text { (bust) }\end{array}$ & $\begin{array}{l}\text { Peak- } \\
\text { to- } \\
\text { trough }\end{array}$ & $\begin{array}{c}\text { Strength } \\
\text { of } \\
\text { recovery }\end{array}$ & $\begin{array}{l}\text { Time to } \\
\text { recovery }\end{array}$ & Peaks \\
\hline ARG & 15.0 & -3.6 & 1.0 & 1.3 & 4.1 & -6.9 & 2.5 & 6.4 & $\begin{array}{r}1994 Q 4 \text { 1998Q2 2001Q1 2008Q3 2011Q4 2013Q3 } \\
2015 Q 2\end{array}$ \\
\hline \multicolumn{10}{|l|}{ AUS } \\
\hline AUT & 2.7 & -0.4 & 0.5 & 0.3 & 3.7 & -2.2 & 1.6 & 4.3 & 2000Q4 2008Q1 2012Q1 \\
\hline BEL & 1.8 & -0.4 & 0.4 & 0.4 & 4.0 & -1.8 & 2.6 & 3.3 & 1992Q1 2000Q4 2008Q2 2012Q1 \\
\hline BRA & 4.5 & -1.4 & 0.8 & 0.6 & 4.2 & -3.1 & 3.6 & 2.0 & 1991Q1 1995Q4 2000Q4 2002Q4 2008Q3 2014Q1 \\
\hline CAN & 2.7 & -0.6 & 0.4 & 0.4 & 2.5 & -2.4 & 1.7 & 3.5 & 2008Q3 2014Q4 \\
\hline CHE & 0.9 & -0.5 & 0.3 & 0.3 & 2.3 & -1.3 & 1.2 & 3.2 & $1992 Q 1$ 1996Q1 1998Q2 2001Q2 2002Q3 2008Q3 \\
\hline $\mathrm{CHL}$ & 2.7 & -0.5 & 0.8 & 1.0 & 3.5 & -3.6 & 5.5 & 3.5 & 1998Q2 2008Q2 \\
\hline \multicolumn{10}{|l|}{$\mathrm{CHN}$} \\
\hline COL & 3.6 & -0.7 & 1.1 & 0.4 & 3.7 & -2.7 & 3.5 & 4.7 & 1995Q4 1998Q2 2015Q4 \\
\hline CRI & 0.9 & -0.3 & 0.9 & 0.8 & 3.0 & -2.0 & 3.1 & 2.5 & 1995Q1 2008Q3 \\
\hline CZE & 8.0 & -2.7 & 0.7 & 1.6 & 4.2 & -7.8 & 2.8 & 16.8 & 1990Q4 1992Q4 1996Q4 2008Q3 2011Q4 \\
\hline DEU & 1.8 & -0.6 & 0.5 & 0.7 & 2.8 & -2.1 & 1.7 & 4.2 & 1992Q1 1995Q3 2002Q3 2004Q2 2008Q1 2012Q3 \\
\hline DNK & 3.6 & -1.1 & 0.6 & 0.6 & 4.0 & -2.6 & 2.7 & 6.5 & 1992Q1 1997Q2 2006Q2 2007Q4 \\
\hline ESP & 1.8 & -1.0 & 0.2 & 0.5 & 7.7 & -4.4 & 3.9 & 14.7 & 1992Q1 2008Q2 2010Q3 \\
\hline EST & 6.5 & -2.8 & 1.6 & 2.3 & 5.5 & -11.7 & 9.1 & 14.5 & 1998Q1 2007Q4 \\
\hline FIN & 8.0 & -1.5 & 0.6 & 1.2 & 5.7 & -4.8 & 3.0 & 9.0 & 2007Q4 2011Q4 2013Q3 \\
\hline FRA & 0.9 & -0.2 & 0.3 & 0.3 & 3.3 & -1.6 & 1.2 & 4.0 & 1992Q2 2008Q1 2012Q3 \\
\hline GBR & 2.7 & -0.3 & 0.4 & 0.8 & 5.0 & -6.3 & 2.4 & 16.0 & $2008 Q 1$ \\
\hline GRC & 10.7 & -2.2 & 0.9 & 0.8 & 9.0 & -8.5 & 1.5 & 5.7 & 1992Q1 2004Q3 2007Q2 2014Q3 \\
\hline HUN & 3.7 & -0.8 & 0.3 & 1.0 & 4.0 & -3.0 & 2.1 & 7.3 & 1995Q1 2006Q4 2008Q2 2011Q4 \\
\hline IDN & 3.6 & -0.6 & 1.7 & 1.8 & 3.5 & -9.2 & 8.1 & 9.0 & 1994Q2 1997Q3 \\
\hline IND & 0.9 & 0.0 & & 0.0 & 2.0 & -0.2 & 6.9 & 1.0 & $2008 Q 3$ \\
\hline IRL & 4.5 & -1.8 & 1.1 & 1.3 & 5.5 & -6.9 & 5.2 & 9.0 & 2007Q4 2012Q2 \\
\hline ISL & 10.7 & -2.6 & 1.7 & 1.1 & 4.0 & -4.1 & 3.2 & 5.3 & 1991Q1 1994Q3 2007Q4 2011Q4 2014Q3 2016Q4 \\
\hline ISR & 0.0 & -0.5 & 0.8 & 0.2 & 3.5 & -1.8 & 1.9 & 5.0 & 2000Q3 2011Q4 \\
\hline ITA & 3.6 & -0.9 & 0.4 & 0.3 & 4.4 & -2.4 & 1.9 & 2.2 & $\begin{array}{r}1992 Q 1 \text { 1997Q4 2001Q1 2002Q4 2008Q1 2011Q2 } \\
2013 Q 3\end{array}$ \\
\hline JPN & 3.6 & -1.2 & 0.7 & 0.7 & 3.7 & -3.0 & 2.8 & 5.7 & 1993Q1 1997Q1 2001Q1 2008Q1 2010Q3 2012Q1 \\
\hline KOR & 2.7 & -0.4 & & 3.9 & 3.0 & -8.1 & 6.8 & 4.0 & 1997Q3 \\
\hline LTU & 3.3 & -1.1 & 1.1 & 3.4 & 5.0 & -9.8 & 6.7 & 10.0 & 1998Q3 2008Q2 \\
\hline LUX & 2.7 & -1.6 & 1.4 & 0.7 & 3.4 & -2.9 & 4.8 & 3.0 & 1994Q4 2002Q2 2007Q4 2011Q1 2015Q1 \\
\hline LVA & 6.5 & -2.7 & 1.9 & 1.3 & 6.5 & -11.7 & 6.9 & 15.5 & 1998Q2 2007Q3 \\
\hline MEX & 3.6 & -0.7 & 0.7 & 1.0 & 3.7 & -6.9 & 4.0 & 5.7 & 1994Q4 2000Q3 2008Q3 \\
\hline NLD & 1.8 & -0.6 & 0.4 & 1.0 & 5.5 & -3.2 & 1.7 & 15.0 & 2008Q2 $2011 Q 1$ \\
\hline NOR & 1.8 & -1.4 & 1.1 & 0.6 & 3.2 & -1.9 & 3.0 & 3.6 & 1992Q3 2002Q2 2007Q4 2010Q1 2016Q1 \\
\hline NZL & 1.8 & -1.1 & 0.7 & 0.8 & 3.2 & -2.5 & 3.5 & 3.2 & 1990Q4 1997Q3 2000Q1 2007Q4 2010Q2 \\
\hline POL & 3.6 & -1.4 & 1.3 & 0.0 & 2.0 & -0.2 & 2.2 & 1.0 & $2001 Q 3$ \\
\hline PRT & 4.5 & -1.0 & 0.5 & 0.5 & 6.3 & -4.4 & 3.4 & 9.3 & 1992Q1 2002Q1 2008Q1 2010Q3 \\
\hline RUS & 9.8 & -2.0 & 0.9 & 1.2 & 4.3 & -7.4 & 4.7 & 9.0 & 1995Q3 1997Q4 2008Q2 2014Q2 \\
\hline SVK & 2.9 & -0.7 & 1.4 & 1.3 & 4.0 & -6.2 & 3.4 & 8.0 & 1998Q4 \\
\hline SVN & 9.8 & -2.1 & 0.5 & 1.3 & 5.5 & -7.1 & 3.0 & 20.0 & 2008Q2 2011Q2 \\
\hline SWE & 2.7 & -0.7 & 0.8 & 1.3 & 5.0 & -4.3 & 4.1 & 5.0 & 2007Q4 2011Q3 \\
\hline TUR & 8.0 & -3.9 & 1.6 & 2.4 & 3.0 & -8.8 & 7.5 & 4.6 & 1993Q4 1998Q3 2000Q3 2007Q1 2008Q1 \\
\hline USA & 1.8 & -0.4 & 0.5 & 0.6 & 4.0 & -2.7 & 2.6 & 5.5 & 1990Q3 2007Q4 \\
\hline ZAF & 1.8 & -0.6 & 0.4 & 0.5 & 3.5 & -1.5 & 1.6 & 2.5 & 2008Q3 2015Q1 \\
\hline
\end{tabular}

Note: Based on quarterly growth rate of real GDP from 1990 to 2017. See Table 2 for definitions. 
Table B.2. Real house price cycles

\begin{tabular}{|c|c|c|c|c|c|c|c|c|c|}
\hline & $\begin{array}{l}\text { Downturn } \\
\text { probability }\end{array}$ & Q5 & $\begin{array}{l}\text { Volatility } \\
\text { (boom) }\end{array}$ & $\begin{array}{c}\text { Volatility } \\
\text { (bust) }\end{array}$ & $\begin{array}{l}\text { Duration } \\
\text { (bust) }\end{array}$ & $\begin{array}{l}\text { Peak- } \\
\text { to- } \\
\text { trough }\end{array}$ & $\begin{array}{c}\text { Strength } \\
\text { of } \\
\text { recovery }\end{array}$ & $\begin{array}{l}\text { Time to } \\
\text { recovery }\end{array}$ & Peaks \\
\hline \multicolumn{10}{|l|}{ ARG } \\
\hline AUS & 10.7 & -1.9 & 1.1 & 0.8 & 5.8 & -4.8 & 7.6 & 5.2 & 1991Q3 1994Q3 2004Q1 2008Q1 2010Q2 \\
\hline AUT & 6.9 & -2.8 & 0.9 & 2.6 & 4.0 & -5.6 & 4.5 & 12.3 & $2001 Q 12002 Q 32007 Q 3$ \\
\hline BEL & 0.9 & -1.0 & 0.9 & 0.3 & 2.3 & -1.2 & 2.0 & 1.7 & 1990Q4 1992Q2 2000Q1 2008Q4 2010Q4 2013Q1 2015Q4 \\
\hline \multicolumn{10}{|l|}{ BRA } \\
\hline CAN & 5.4 & -2.0 & 1.3 & 0.9 & 6.8 & -4.8 & 3.8 & 10.3 & 1991Q2 1997Q2 2008Q2 2010Q2 \\
\hline $\mathrm{CHE}$ & 17.9 & -2.9 & 1.0 & 0.5 & 9.3 & -5.7 & 6.5 & 9.8 & 1994Q3 2001Q4 2007Q1 2008Q4 \\
\hline $\mathrm{CHL}$ & 14.1 & -2.6 & 1.2 & 0.9 & 6.0 & -5.4 & 6.7 & 5.5 & $2004 Q 42011 Q 12013 Q 42015 Q 3$ \\
\hline $\mathrm{CHN}$ & 16.7 & -1.8 & 0.8 & 0.8 & 4.5 & -5.0 & 8.3 & 4.5 & 2011Q2 2014Q1 \\
\hline $\mathrm{COL}$ & 19.6 & -4.2 & 0.9 & 2.1 & 8.0 & -14.9 & 0.0 & 31.3 & 1996Q2 1998Q1 2001Q4 \\
\hline \multicolumn{10}{|l|}{ CRI } \\
\hline CZE & 12.5 & -1.8 & & 1.0 & 21.0 & -13.8 & & 12.0 & $2008 Q 3$ \\
\hline DEU & 6.3 & -1.5 & 0.6 & 0.8 & 9.2 & -4.6 & -0.5 & 13.8 & 1991Q1 1995Q1 1999Q4 2006Q4 2009Q4 $2013 Q 2$ \\
\hline DNK & 15.2 & -2.7 & 0.7 & 1.2 & 6.0 & -10.4 & 2.7 & 5.3 & 1991Q4 1994Q12007Q12010Q4 \\
\hline ESP & 24.1 & -3.7 & 1.5 & 1.5 & 14.7 & -21.3 & 11.9 & 11.5 & 1991Q4 1997Q2 2007Q3 \\
\hline EST & 19.2 & -8.5 & 2.2 & 3.3 & 6.0 & -27.4 & 8.9 & 2.0 & 2007Q2 2016Q4 \\
\hline FIN & 17.0 & -4.6 & 1.3 & 0.8 & 7.8 & -5.4 & 9.3 & 4.3 & 1994Q2 2000Q2 2008Q1 2010Q3 \\
\hline FRA & 11.6 & -1.6 & 0.8 & 0.6 & 15.0 & -11.8 & 20.8 & 12.5 & 1991Q1 2007Q4 2011Q3 \\
\hline GBR & 19.6 & -3.0 & 1.0 & 1.4 & 8.0 & -10.7 & 10.4 & 4.5 & 1994Q4 2007Q4 2010Q1 \\
\hline GRC & 27.4 & -3.6 & 1.1 & 1.1 & 21.5 & -24.0 & 9.5 & 3.0 & $2003 Q 12007 Q 3$ \\
\hline HUN & 34.1 & -4.5 & & 1.8 & 24.0 & -34.6 & & & 2007Q4 \\
\hline IDN & 39.1 & -3.3 & 1.3 & 0.1 & 2.0 & -0.9 & 0.4 & & 2016Q2 \\
\hline \multicolumn{10}{|l|}{ IND } \\
\hline IRL & 20.5 & -5.2 & 1.9 & 1.4 & 11.3 & -19.7 & 5.2 & 2.5 & 1991Q4 2001Q1 2007Q1 \\
\hline ISL & 15.4 & -7.0 & 0.7 & 1.5 & 4.7 & -13.3 & 4.6 & 10.7 & $2006 Q 12007 Q 42012 Q 3$ \\
\hline ISR & 17.7 & -2.5 & 1.3 & 1.0 & 6.6 & -7.6 & 3.5 & 17.6 & 1997Q32002Q12004Q2 2005Q42011Q3 \\
\hline ITA & 31.3 & -2.2 & 0.6 & 0.9 & 15.5 & -17.9 & 11.5 & 27.0 & 1991Q4 2008Q1 \\
\hline JPN & 25.0 & -1.7 & 0.6 & 0.6 & 27.0 & -16.0 & 2.2 & 3.5 & 1991Q1 2010Q4 2013Q4 \\
\hline KOR & 30.4 & -3.7 & 0.8 & 0.8 & 8.7 & -10.6 & 8.1 & 6.0 & 1990Q4 1999Q3 2003Q4 2008Q3 2009Q4 2011Q4 2016Q1 \\
\hline LTU & 20.8 & -5.5 & 0.9 & 3.5 & 5.7 & -16.2 & 1.5 & 4.5 & $2008 Q 12011 Q 12013 Q 1$ \\
\hline LUX & 0.0 & -1.0 & & 1.1 & 8.0 & -3.9 & 5.7 & 2.0 & $2007 Q 3$ \\
\hline LVA & 20.8 & -12.4 & 0.0 & 3.9 & 6.5 & -26.2 & 5.1 & 4.0 & $2008 Q 12011 Q 1$ \\
\hline MEX & 1.9 & -1.0 & 0.6 & 0.5 & 4.2 & -2.0 & 1.4 & 5.8 & 2006Q1 2007Q2 2009Q4 2011Q4 2013Q2 2016Q1 \\
\hline NLD & 12.5 & -1.9 & 1.5 & 1.2 & 25.0 & -25.0 & & & $2007 Q 4$ \\
\hline NOR & 13.4 & -2.8 & 1.3 & 1.1 & 3.3 & -4.8 & 6.1 & 3.3 & 1998Q2 2002Q2 2007Q3 2013Q2 \\
\hline NZL & 12.5 & -1.7 & 0.9 & 0.9 & 5.0 & -7.3 & 2.8 & 12.0 & 1997Q2 1999Q3 2007Q3 2009Q4 \\
\hline \multicolumn{10}{|l|}{ POL } \\
\hline PRT & 19.6 & -2.5 & 0.7 & 0.7 & 9.7 & -9.8 & 0.1 & 13.5 & 1992Q2 1994Q4 2001Q2 2005Q3 2009Q4 2014Q2 \\
\hline RUS & 36.8 & -5.1 & 6.5 & 8.5 & 4.0 & -22.7 & -11.4 & & 2008Q3 2010Q2 \\
\hline SVK & 25.0 & -4.8 & & 2.6 & 18.0 & -30.4 & 19.4 & & $2008 Q 2$ \\
\hline SVN & 31.8 & -4.6 & 0.6 & 1.3 & 13.5 & -16.2 & 3.2 & 1.0 & 2008Q1 2015Q2 \\
\hline SWE & 12.5 & -3.3 & 1.0 & 0.7 & 4.7 & -5.1 & 5.6 & 5.0 & 1994Q32007Q3 2010Q4 \\
\hline TUR & 3.1 & -2.0 & & 1.1 & 4.0 & -4.8 & 4.6 & 5.0 & $2010 Q 4$ \\
\hline USA & 13.4 & -1.9 & 0.4 & 0.9 & 14.0 & -14.3 & 1.6 & 4.0 & 1992Q1 2006Q1 \\
\hline ZAF & 14.3 & -2.8 & 1.2 & 1.1 & 6.7 & -7.4 & 3.4 & 9.8 & 1991Q4 1994Q3 1998Q1 2001Q4 2007Q3 2010Q1 2016Q1 \\
\hline
\end{tabular}

Note: Based on quarterly growth rates of real house prices from 1990 to 2017. See Table 2 for definitions. 
Table B.3. Real housing investment cycles

\begin{tabular}{|c|c|c|c|c|c|c|c|c|c|}
\hline & $\begin{array}{l}\text { Downturn } \\
\text { probability }\end{array}$ & Q5 & $\begin{array}{l}\text { Volatility } \\
\text { (boom) }\end{array}$ & $\begin{array}{l}\text { Volatility } \\
\text { (bust) }\end{array}$ & $\begin{array}{l}\text { Duration } \\
\text { (bust) }\end{array}$ & $\begin{array}{l}\text { Peak- } \\
\text { to- } \\
\text { trough }\end{array}$ & $\begin{array}{c}\text { Strength } \\
\text { of } \\
\text { recovery }\end{array}$ & $\begin{array}{l}\text { Time to } \\
\text { recovery }\end{array}$ & Peaks \\
\hline \multicolumn{10}{|l|}{ ARG } \\
\hline AUS & 22.3 & -4.3 & 2.5 & 2.6 & 4.7 & -14.1 & 9.9 & 10.7 & 1994Q2 2000Q2 2004Q1 2007Q1 2008Q2 2011Q2 \\
\hline AUT & 18.8 & -3.3 & 1.9 & 1.7 & 6.7 & -7.7 & 2.6 & 8.0 & 1996Q3 1998Q4 2005Q3 2008Q1 2011Q2 2012Q3 2013Q4 \\
\hline BEL & 25.0 & -2.9 & 1.1 & 1.1 & 5.2 & -8.1 & 6.4 & 13.4 & $\begin{array}{r}1990 Q 31992 Q 41995 Q 1 \text { 1997Q2 1999Q2 2007Q4 2010Q3 } \\
2012 Q 22014 Q 4\end{array}$ \\
\hline \multicolumn{10}{|l|}{ BRA } \\
\hline CAN & 18.8 & -5.9 & 1.7 & 1.4 & 4.0 & -7.1 & 7.9 & 5.5 & $\begin{array}{r}1992 Q 31994 Q 21997 Q 42002 Q 42006 Q 12007 Q 42010 Q 1 \\
2012 Q 1\end{array}$ \\
\hline $\mathrm{CHE}$ & 20.4 & -2.7 & 1.7 & 1.3 & 12.3 & -14.5 & 11.2 & 32.3 & 1995Q1 1998Q1 2005Q1 \\
\hline $\mathrm{CHL}$ & 23.7 & -4.0 & 1.4 & 1.1 & 6.3 & -12.8 & 6.0 & 8.0 & 1998Q1 2006Q1 2008Q12011Q4 \\
\hline \multicolumn{10}{|l|}{$\mathrm{CHN}$} \\
\hline $\mathrm{COL}$ & 20.8 & -10.7 & 5.3 & 6.2 & 4.5 & -14.9 & 17.2 & 4.3 & $2004 Q 42006 Q 32008 Q 32014 Q 3$ \\
\hline \multicolumn{10}{|l|}{ CRI } \\
\hline CZE & 15.9 & -5.7 & 4.5 & 2.5 & 4.0 & -7.9 & 7.2 & 6.7 & 1996Q3 1999Q2 2000Q4 2002Q1 2007Q1 2012Q2 \\
\hline DEU & 20.5 & -3.5 & 2.2 & 1.4 & 4.4 & -7.0 & 6.0 & 6.0 & $\begin{array}{r}1992 Q 41995 Q 21998 Q 11999 Q 32003 Q 32006 Q 42008 Q 1 \\
2010 Q 22012 Q 32014 Q 1\end{array}$ \\
\hline DNK & 25.0 & -9.2 & 3.3 & 3.1 & 4.7 & -16.1 & 8.0 & 6.2 & 1992Q3 2000Q1 2001Q42004Q2 2006Q3 2011Q12012Q3 \\
\hline ESP & 27.7 & -4.5 & 2.2 & 1.4 & 14.7 & -23.5 & 10.9 & 4.0 & 1990Q3 1996Q1 2006Q4 \\
\hline EST & 19.6 & -15.4 & 9.8 & 8.6 & 6.6 & -28.4 & 35.6 & 2.8 & 1997Q4 2004Q1 2006Q4 2014Q1 2016Q2 \\
\hline FIN & 32.1 & -5.5 & 3.1 & 1.9 & 8.5 & -16.8 & 17.3 & 7.0 & 1995Q1 2000Q3 2006Q4 2011Q1 \\
\hline FRA & 15.2 & -2.2 & 0.4 & 0.6 & 7.3 & -6.6 & 2.2 & 9.0 & 1995Q1 2007Q2 2010Q4 2013Q2 \\
\hline GBR & 26.8 & -6.9 & 2.9 & 3.4 & 6.4 & -13.1 & 7.4 & 8.8 & 1993Q4 1996Q4 2005Q2 2007Q1 2010Q3 2011Q42014Q3 \\
\hline GRC & 40.2 & -24.1 & 13.3 & 10.1 & 8.8 & -44.3 & -5.2 & 13.3 & 1991Q1 2000Q2 2004Q3 2006Q1 2007Q3 2011Q3 \\
\hline HUN & 34.8 & -7.8 & 1.5 & 2.5 & 12.0 & -36.7 & 30.6 & 7.0 & 1996Q4 2004Q3 2009Q1 \\
\hline \multicolumn{10}{|l|}{ IDN } \\
\hline \multicolumn{10}{|l|}{ IND } \\
\hline IRL & 22.3 & -12.6 & 2.7 & 3.9 & 9.3 & -27.1 & 14.9 & 2.0 & 1992Q2 1997Q3 2001Q2 2005Q4 \\
\hline ISL & 27.7 & -10.9 & 2.9 & 3.9 & 4.9 & -18.4 & 11.2 & 10.5 & 1991Q4 1994Q2 1996Q3 2001Q2 2007Q4 2012Q2 $2014 Q 2$ \\
\hline ISR & 19.6 & -6.1 & 3.3 & 2.6 & 6.4 & -14.9 & 10.3 & 21.2 & 1992Q1 1997Q1 2000Q1 2001Q3 2014Q3 \\
\hline ITA & 18.8 & -3.3 & 1.5 & 2.0 & 9.0 & -9.9 & -1.2 & 6.3 & 1991Q4 1995Q4 1997Q4 2001Q2 2006Q4 2010Q2 \\
\hline JPN & 29.5 & -8.2 & 2.2 & 2.2 & 6.2 & -16.1 & 2.8 & 3.5 & $\begin{array}{r}1990 Q 31994 Q 31996 Q 4 \text { 1999Q3 2004Q3 2005Q4 2008Q4 } \\
\text { 2011Q3 2014Q1 }\end{array}$ \\
\hline KOR & 23.2 & -8.5 & 4.2 & 2.9 & 4.3 & -15.5 & 6.6 & 10.4 & $\begin{array}{r}1991 Q 41996 Q 31997 Q 42002 Q 12004 Q 12007 Q 12009 Q 3 \\
2011 Q 4\end{array}$ \\
\hline LTU & 27.2 & -20.4 & 7.2 & 12.1 & 4.0 & -25.8 & 26.6 & 6.8 & 1999Q1 2000Q3 2004Q4 2008Q2 2015Q3 \\
\hline LUX & 30.4 & -21.4 & 11.7 & 8.4 & 4.6 & -27.2 & 17.6 & 10.4 & 1995Q3 1998Q1 1999Q3 2004Q1 2008Q1 2012Q1 2014Q1 \\
\hline LVA & 27.2 & -37.2 & 17.6 & 24.6 & 8.2 & -52.8 & 43.8 & 13.7 & 1996Q4 2000Q4 2007Q4 2012Q32015Q2 \\
\hline MEX & 23.0 & -5.1 & 3.2 & 2.3 & 3.3 & -7.6 & 6.1 & 3.3 & $\begin{array}{r}1994 Q 41996 Q 11999 Q 12000 Q 22004 Q 12006 Q 32008 Q 2 \\
2010 Q 12011 Q 4\end{array}$ \\
\hline NLD & 25.9 & -7.8 & 3.3 & 2.7 & 7.8 & -13.5 & 8.7 & 2.8 & 1992Q4 1994Q4 2000Q1 2001Q2 2007Q1 2008Q2 \\
\hline NOR & 20.5 & -5.3 & 3.1 & 1.4 & 4.8 & -7.3 & 10.0 & 4.0 & 1994Q4 1998Q1 1999Q4 2002Q1 2007Q2 2013Q1 \\
\hline NZL & 17.9 & -10.2 & 4.1 & 4.2 & 4.9 & -16.6 & 9.6 & 10.1 & 1992Q1 1997Q3 2000Q1 2004Q2 2007Q3 2010Q2 2016Q2 \\
\hline POL & 17.4 & -3.8 & 1.6 & 1.5 & 5.8 & -9.3 & 7.8 & 7.0 & $2000 Q 12002 Q 22008 Q 22012 Q 22014 Q 1$ \\
\hline PRT & 33.0 & -5.7 & 1.9 & 2.0 & 11.0 & -20.5 & 7.5 & 2.0 & 1992Q4 1995Q2 2000Q1 2002Q1 2005Q1 \\
\hline \multicolumn{10}{|l|}{ RUS } \\
\hline SVK & 23.9 & -12.1 & 5.5 & 8.4 & 6.4 & -23.1 & 14.3 & 7.0 & 2000Q3 2005Q1 2009Q3 2013Q4 2016Q4 \\
\hline SVN & 38.0 & -5.6 & 1.8 & 1.9 & 11.0 & -21.6 & 7.9 & 7.3 & 1997Q4 1999Q3 2001Q3 2008Q2 \\
\hline SWE & 26.8 & -9.7 & 2.6 & 3.5 & 7.0 & -21.8 & 19.3 & 11.0 & 1996Q1 2007Q2 2011Q3 \\
\hline \multicolumn{10}{|l|}{ TUR } \\
\hline USA & 20.5 & -6.5 & 1.5 & 1.0 & 4.5 & -12.1 & 7.5 & 2.6 & 1994Q2 1996Q2 2000Q1 2005Q3 2013Q3 2016Q1 \\
\hline ZAF & 23.2 & -5.0 & 2.4 & 1.9 & 6.6 & -13.0 & 10.0 & 13.5 & 1992Q2 1995Q1 1996Q3 2001Q1 2005Q4 2007Q2 2015Q3 \\
\hline
\end{tabular}

Note: Based on quarterly growth rates of real housing investment from 1990 to 2017. See Table 2 for definitions. 


\section{Annex C. Description of policy variables}

\begin{tabular}{|c|c|c|}
\hline Variable & Description & Source \\
\hline LTV caps & Maximum loan-to-value ratios applied to mortgage loans. & $\begin{array}{l}\text { ECB's Macroprudential Policies } \\
\text { Evaluation Database (MaPPED) } \\
\text { complemented by own research }\end{array}$ \\
\hline Capital requirements & $\begin{array}{l}\text { Minimum regulatory Tier } 1 \text { ratio multiplied with unweighted average of risk } \\
\text { weights for mortgage loans with an LTV ranging from } 50 \text { to } 130 \text {. }\end{array}$ & $\begin{array}{l}\text { ECB's Macroprudential Policies } \\
\text { Evaluation Database (MaPPED) } \\
\text { complemented by own research }\end{array}$ \\
\hline Rent control & $\begin{array}{l}\text { Index reflecting on the number of regulations that restrict rent increases } \\
\text { including real rent freezes, nominal rent freezes, rent level control, limits of } \\
\text { decontrolling (e.g. change of tenant, new or vacant dwelling) as well as } \\
\text { restrictions on subletting }\end{array}$ & DIW (Kholodilin, 2018[29]) \\
\hline Tenure security & $\begin{array}{l}\text { Index capturing the intensity of regulation protecting tenants from eviction } \\
\text { including the prohibition of short-term tenancies. }\end{array}$ & DIW (Kholodilin, 2018[29]) \\
\hline Social rental market & $\begin{array}{l}\text { Number of social rental dwellings as a share of the total number of } \\
\text { dwellings, } 2015 \text { or latest year available. }\end{array}$ & OECD Affordable Housing Database \\
\hline Housing allowances & Public spending on housing allowances as \% of GDP, 2015. & OECD Affordable Housing Database \\
\hline $\begin{array}{l}\text { Property tax rate } \\
\text { (owner-occupied) }\end{array}$ & $\begin{array}{l}\text { Marginal effective tax rates (METR) on owner-occupied are derived as the } \\
\text { differences between the pre- and post-tax rates of return of a marginal } \\
\text { investment divided by the pre-tax rate of return of that investment where } \\
\text { post-tax real rate is the minimum rate of return necessary to make the } \\
\text { investment worthwhile. }\end{array}$ & $\begin{array}{l}\text { OECD Tax Policy Studies paper (OECD, } \\
\left.2018_{[33]}\right)\end{array}$ \\
\hline $\begin{array}{l}\text { Property tax rate } \\
\text { (rental) }\end{array}$ & $\begin{array}{l}\text { Marginal effective tax rates (METR) on rental dwellings are derived as the } \\
\text { differences between the pre- and post-tax rates of return of a marginal } \\
\text { investment divided by the pre-tax rate of return of that investment where } \\
\text { post-tax real rate is the minimum rate of return necessary to make the } \\
\text { investment worthwhile. }\end{array}$ & $\begin{array}{l}\text { OECD Tax Policy Studies paper (OECD, } \\
2018[33])\end{array}$ \\
\hline $\begin{array}{l}\text { Urban sprawl } \\
\text { (restrictiveness) }\end{array}$ & $\begin{array}{l}\text { Composite indicator derived from the first principal component of changes } \\
\text { in } 8 \text { urban sprawl indicators from } 2000 \text { to } 2014 \text {. The indicator is associated } \\
\text { with an increasing share of low populated areas and decentralisation. } \\
\text { "Urban sprawl restrictiveness" is defined as the negative of the urban sprawl } \\
\text { composite indicator. }\end{array}$ & $\begin{array}{l}\text { Own calculations based on OECD's } \\
\text { Urban Sprawl indicators (OECD, } \\
2018_{[37]} \text { ) }\end{array}$ \\
\hline $\begin{array}{l}\text { Densification } \\
\text { (restrictiveness) }\end{array}$ & $\begin{array}{l}\text { Composite indicator derived from the second principal component of } \\
\text { changes in } 8 \text { urban sprawl indicators from } 2000 \text { to } 2014 \text {. "Densification } \\
\text { restrictiveness" is defined as the negative of the densification composite } \\
\text { indicator. }\end{array}$ & $\begin{array}{l}\text { Own calculations based on OECD's } \\
\text { Urban Sprawl indicators (OECD, } \\
\left.2018_{[3]]}\right)\end{array}$ \\
\hline $\begin{array}{l}\text { Zoning } \\
\text { (restrictiveness) }\end{array}$ & $\begin{array}{l}\text { Composite indicator derived from the third principal component of changes } \\
\text { in } 8 \text { urban sprawl indicators from } 2000 \text { to } 2014 \text {. The indicator is associated } \\
\text { with urban expansion and declines in fragmentation. "Zoning } \\
\text { restrictiveness" is defined as the negative of the zoning composite indicator. }\end{array}$ & $\begin{array}{l}\text { Own calculations based on OECD's } \\
\text { Urban Sprawl indicators (OECD, } \\
2018[37])\end{array}$ \\
\hline
\end{tabular}




\section{Annex D. Gauging land use policies from urban sprawl data}

In the absence of harmonised quantitative indicators for land use regulation, outcome variables of urban sprawl could serve as a proxy for impediments to housing supply. Recent work at the OECD has produced a range of useful metrics in this regard $\left(\mathrm{OECD}, 2018_{[37]}\right)$. To summarise the information contained in 8 urban sprawl indicators, more precisely their change between 2000 and 2014, principal component analysis can be used (Table D1). The resulting first principal component reflects urban sprawl in the narrow sense and is associated with an increasing share of people living in low-density areas. The second principal component reflects densification of areas outside the urban core leading to polycentric structures with more but smaller urban centres. The third principal component reflects the extension of urban footprint and is associated with an increase of developed land and a reduction of fragmentation.

Table D.1. Urban sprawl indicators - principal component analysis

\begin{tabular}{|c|c|c|c|c|}
\hline Variable & Description & PC1 & PC2 & PC3 \\
\hline Population density & Average functional urban area population density: number of inhabitants $/ \mathrm{km}^{2}$ & -0.90 & & \\
\hline Fragmentation & Fragmentation index: number of urban fabric fragments per $\mathrm{km}^{2}$ & & & -0.55 \\
\hline Polycentricity & Number of urban centres & & 0.75 & \\
\hline Coefficient of variation & Coefficient of variation of population density & & 0.60 & \\
\hline Decentralisation & Share of functional urban area population living outside of urban centres & & -0.69 & \\
\hline Land to density allocation & $\begin{array}{l}\text { Percentage of urban footprint occupying areas of density below } 2500 \\
\text { inhabitants } / \mathrm{km}^{2}\end{array}$ & 0.90 & & \\
\hline Population to density allocation & $\begin{array}{l}\text { Percentage of population living in areas with a density below } 2500 \\
\text { inhabitants } / \mathrm{km}^{2}\end{array}$ & 0.92 & & \\
\hline Artificial area & Sum of functional urban area's artificial area in $\mathrm{km}^{2}$ & & & 0.89 \\
\hline
\end{tabular}

Note: Principal component analysis on the change between 2000 and 2014 of eight urban sprawl indicators is performed. The table shows loadings with a contribution of more than $15 \%$ per principal component (PC) for the first three PCs that explain more than $75 \%$ of the overall variation in the data.

Source: Rethinking Urban Sprawl, Moving towards Sustainable Cities (OECD, 2018[37]).

Non-policy drivers of urban sprawl include population growth, the rise in household income, the decline of commuting costs and individual preferences for living in low-density areas. Assuming common trends for individual preferences and commuting costs across countries, controlling for increases in household income allows to derive unexplained changes to urban sprawl, densification and the extension of the urban footprint. The inverse of these indicators are then used as proxies for the respective restrictiveness across countries (Figure D1). 


\section{Figure D1. Land use restrictiveness indicators}
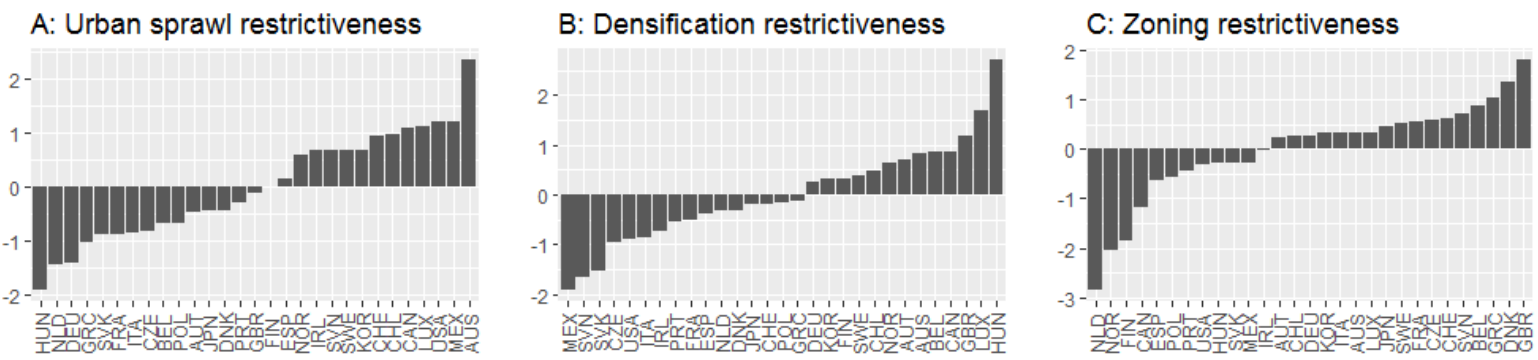

Note: Based on composite indicators for urban sprawl, densification and newly developed urban land drawn from principal component analysis of changes to urban sprawl indicators between 2000 and 2014 (Table ). Restrictiveness indicators are obtained as the inverse of the principal components after controlling for the increase in disposable household income.

Source: Own calculations. 


\section{Annex E. Summary statistics of policy variables}

\begin{tabular}{|c|c|c|c|c|c|c|c|c|c|c|c|}
\hline & \multicolumn{2}{|c|}{$\begin{array}{l}\text { Macroprudential } \\
\text { regulation }\end{array}$} & \multicolumn{2}{|c|}{ Rental regulation } & \multicolumn{2}{|c|}{ Public support } & \multicolumn{2}{|c|}{ Property taxation } & \multicolumn{3}{|c|}{ Land use restrictiveness } \\
\hline & $\begin{array}{l}\text { LTV } \\
\text { caps }\end{array}$ & $\begin{array}{c}\text { Capital } \\
\text { require- } \\
\text { ment }\end{array}$ & $\begin{array}{l}\text { Rent } \\
\text { control }\end{array}$ & $\begin{array}{l}\text { Tenure } \\
\text { security }\end{array}$ & $\begin{array}{l}\text { Social } \\
\text { rental } \\
\text { market }\end{array}$ & $\begin{array}{l}\text { Housing } \\
\text { allowances }\end{array}$ & $\begin{array}{l}\text { Property } \\
\text { tax rate } \\
\text { (owner- } \\
\text { occupied) }\end{array}$ & $\begin{array}{l}\text { Property } \\
\text { tax rate } \\
\text { (rental) }\end{array}$ & $\begin{array}{l}\text { Urban } \\
\text { sprawl }\end{array}$ & $\begin{array}{l}\text { Densifi- } \\
\text { cation }\end{array}$ & Zoning \\
\hline$\overline{A R G}$ & & & 0.27 & 0.75 & & & 0.28 & 0.57 & & & \\
\hline AUS & & 8.00 & 0.17 & 0.00 & 4.90 & 0.27 & 0.15 & 0.88 & 2.33 & 0.85 & 0.34 \\
\hline AUT & & 8.00 & 0.17 & 0.75 & 26.20 & 0.16 & 0.15 & 0.59 & -0.48 & 0.70 & 0.23 \\
\hline BEL & & 8.00 & 0.17 & 0.25 & & & 0.49 & 0.51 & -0.69 & 0.86 & 0.89 \\
\hline BRA & & & 0.00 & 0.50 & & & & & & & \\
\hline CAN & 94.87 & 8.00 & 0.33 & 0.25 & 4.10 & & 0.39 & 0.75 & 1.08 & 0.86 & -1.17 \\
\hline CHE & 93.33 & 8.00 & 0.33 & 0.50 & & & 0.23 & 0.28 & 0.94 & -0.17 & 0.62 \\
\hline $\mathrm{CHL}$ & & & 0.17 & 0.25 & & 0.01 & 0.21 & 0.21 & 0.96 & 0.47 & 0.27 \\
\hline $\mathrm{CHN}$ & 75.26 & 8.00 & & & & & & & & & \\
\hline $\mathrm{COL}$ & & & 0.50 & 0.25 & & & 0.17 & 0.17 & & & \\
\hline \multicolumn{12}{|l|}{ CRI } \\
\hline CZE & 97.13 & 8.00 & 0.02 & 0.50 & 0.50 & 0.27 & 0.11 & 0.22 & -0.82 & -0.96 & 0.59 \\
\hline DEU & & 8.00 & 0.40 & 0.50 & 3.90 & 0.59 & 0.19 & 0.66 & -1.40 & 0.26 & 0.27 \\
\hline DNK & 82.37 & 8.00 & 0.77 & 0.40 & 22.20 & 0.48 & 0.21 & 0.49 & -0.44 & -0.30 & 1.36 \\
\hline ESP & & 8.84 & 0.33 & 1.00 & & 0.01 & 0.37 & 0.48 & 0.16 & -0.37 & -0.64 \\
\hline EST & & 8.84 & 0.50 & 0.50 & 1.40 & 0.04 & 0.00 & 0.22 & & & \\
\hline FIN & 99.74 & 8.00 & 0.17 & 0.25 & 12.80 & 0.82 & 0.12 & 0.50 & 0.01 & 0.32 & -1.85 \\
\hline FRA & & 8.00 & 0.32 & 1.00 & 18.70 & 0.83 & 0.23 & 0.47 & -0.88 & -0.50 & 0.57 \\
\hline GBR & & 8.00 & 0.17 & 0.25 & 17.60 & 1.41 & 0.28 & 0.55 & -0.11 & 1.17 & 1.80 \\
\hline GRC & & 8.00 & 0.00 & 0.00 & & & 0.27 & 0.26 & -1.02 & -0.12 & 1.04 \\
\hline HUN & 80.00 & 8.00 & & & 4.00 & & 0.15 & 0.30 & -1.89 & 2.70 & -0.29 \\
\hline IDN & 83.96 & 8.00 & & & & & & & & & \\
\hline IND & 83.75 & 9.00 & & & & & & & & & \\
\hline $\mathbb{R L}$ & & 8.00 & 0.33 & 0.25 & 8.70 & 0.21 & 0.07 & 0.58 & 0.66 & -0.74 & -0.03 \\
\hline ISL & & & 0.00 & 0.25 & & & 0.16 & 0.36 & & & \\
\hline ISR & & & & & & & 0.10 & 0.28 & & & \\
\hline ITA & & 8.00 & 0.17 & 1.00 & & & 0.02 & 0.47 & -0.84 & -0.86 & 0.34 \\
\hline
\end{tabular}




\begin{tabular}{|c|c|c|c|c|c|c|c|c|c|c|c|}
\hline JPN & & 12.00 & & & 3.80 & 0.12 & 0.21 & 0.37 & -0.44 & -0.20 & 0.47 \\
\hline KOR & 67.37 & 14.55 & & & 6.40 & 0.06 & 0.06 & 0.09 & 0.68 & 0.31 & 0.33 \\
\hline LTU & 85.00 & 8.00 & 0.17 & 0.25 & & 0.06 & 0.03 & 0.19 & & & \\
\hline LUX & & 8.00 & 0.67 & 0.50 & 1.60 & & 0.00 & 0.47 & 1.11 & 1.70 & 0.35 \\
\hline LVA & 92.11 & 8.84 & 0.17 & 0.50 & 0.20 & 0.08 & 0.22 & 0.33 & & & \\
\hline MEX & & & 0.00 & 0.25 & & & 0.11 & 0.46 & 1.21 & -1.90 & -0.27 \\
\hline NLD & 104.11 & 8.00 & & & 34.10 & 0.45 & 0.10 & 0.50 & -1.44 & -0.31 & -2.84 \\
\hline NOR & 85.00 & 10.00 & 0.17 & 0.75 & 4.60 & 0.09 & 0.17 & 0.67 & 0.59 & 0.63 & -2.04 \\
\hline NZL & 85.83 & 8.00 & 0.17 & 0.25 & 5.80 & 0.47 & 0.20 & 0.46 & & & \\
\hline POL & 86.05 & 9.68 & 0.33 & 0.50 & 8.30 & 0.09 & 0.06 & 0.15 & -0.66 & -0.15 & -0.56 \\
\hline PRT & & 8.53 & 0.20 & 0.50 & 2.00 & 0.05 & 0.15 & 0.44 & -0.30 & -0.54 & -0.45 \\
\hline RUS & & & 0.17 & 0.25 & & & & & & & \\
\hline SVK & 78.17 & 8.00 & 0.17 & 0.50 & & & 0.00 & 0.21 & -0.89 & -1.53 & -0.28 \\
\hline SVN & & 8.00 & & & 6.40 & & 0.08 & 0.34 & 0.67 & -1.66 & 0.73 \\
\hline SWE & 85.00 & 8.00 & 0.50 & 0.50 & & 0.45 & 0.06 & 0.24 & 0.68 & 0.40 & 0.52 \\
\hline TUR & 76.04 & & 0.31 & 0.25 & & & 0.07 & 0.36 & & & \\
\hline USA & & 8.00 & 0.17 & 0.25 & 4.30 & 0.10 & 0.40 & 0.58 & 1.20 & -0.89 & -0.31 \\
\hline ZAF & & & & & & & 0.23 & 0.59 & & & \\
\hline
\end{tabular}

Note: Averages over 2012-2017 are shown. See Annex C for data description. 


\section{Annex F. Identified episodes of severe downturns}

\begin{tabular}{|c|c|c|c|c|c|}
\hline Countries & 1960s & 1970s & 1980s & 1990s & $2000 \mathrm{~s}$ \\
\hline \multirow[t]{3}{*}{ ARG } & & & & & $2000 q 2-2002 q 2$ \\
\hline & & & & & $2008 q 4-2009 q 3$ \\
\hline & & & & & $2011 q 4-2017 q 1$ \\
\hline \multirow[t]{3}{*}{ AUS } & $1960 q 3-1961 q 4$ & $1971 q 1-1971 q 2$ & $1981 q 4-1983 q 2$ & $1991 q 1-1991 q 2$ & \\
\hline & & $1974 q 1-1974 q 2$ & & & \\
\hline & & $1975 q 3-1975 q 4$ & & & \\
\hline AUT & & & & & $2008 q 2-2010 q 1$ \\
\hline BEL & & $1974 q 2-1975 q 1$ & & $1992 q 2-1993 q 1$ & $2008 q 2-2009 q 2$ \\
\hline \multirow[t]{3}{*}{ BRA } & $1962 q 2-1963 q 2$ & & $1980 q 2-1981 q 4$ & $1998 q 1-1999 q 4$ & $2003 q 1-2003 q 2$ \\
\hline & & & 1987q2-1988q1 & & $2008 q 4-2009 q 1$ \\
\hline & & & $1989 q 2-1990 q 3$ & & $2015 q 1-2016 q 4$ \\
\hline CAN & & $1974 q 3-1975 q 1$ & $1981 q 3-1982 q 4$ & $1989 q 2-1992 q 2$ & $2008 q 4-2009 q 2$ \\
\hline $\mathrm{CHE}$ & $1969 q 1-1969 q 2$ & $1974 q 2-1976 q 2$ & $1981 q 4-1982 q 4$ & $1992 q 4-1993 q 1$ & $2008 q 3-2009 q 2$ \\
\hline $\mathrm{CHL}$ & & & & $1998 q 3-1999 q 2$ & $2000 q 3-2009 q 2$ \\
\hline $\mathrm{CHN}$ & & $1875 q 4-1976 q 4$ & & $1997 q 1$ & $2006 q 2$ \\
\hline $\mathrm{COL}$ & & & & $1998 q 2-1999 q 2$ & $2015 q 1-2015 q 2$ \\
\hline \multirow[t]{2}{*}{ CZE } & & & & $1990 q 3$ & $2008 q 4-2009 q 2$ \\
\hline & & & & $1991 q 1-1992 q 1$ & \\
\hline DEU & & $1974 q 2-1975 q 2$ & $1980 q 2-1982 q 4$ & $1992 q 2-1993 q 4$ & $2008 q 2-2009 q 1$ \\
\hline DNK & & $1974 q 2-1975 q 1$ & 1980q2-1981q1 & $1992 q 2-1993 q 1$ & $2008 q 1-2009 q 2$ \\
\hline ESP & & & & 1992q2-1993q2 & $2008 q 1-2013 q 2$ \\
\hline \multirow[t]{2}{*}{ FIN } & & 1973q2 & $1980 q 4-1981 q 1$ & $1990 q 2-1993 q 2$ & $2008 q 1-2010 q 1$ \\
\hline & & $1975 q 2-1975 q 4$ & & & $2011 q 4-2013 q 1$ \\
\hline FRA & & $1974 q 4-1975 q 3$ & & $1992 q 2-1993 q 1$ & $2008 q 2-2009 q 2$ \\
\hline GBR & & $1973 q 3-1976 q 2$ & $1979 q 3-1981 q 1$ & $1990 q 3-1992 q 2$ & $2008 q 2-2009 q 3$ \\
\hline \multirow[t]{2}{*}{ GRC } & & $1973 q 2-1974 q 1$ & $1980 q 2-1983 q 1$ & 1992q2-1992q4 & $2008 q 2-2014 q 3$ \\
\hline & & & $1986 q 2-1987 q 1$ & & \\
\hline HUN & & & & $1991 q 2-1993 q 1$ & $2008 q 3-2010 q 1$ \\
\hline IND & & & & $1996 q 1$ & \\
\hline IRE & & & & & $2007 q 2-2013 q 1$ \\
\hline \multirow[t]{6}{*}{ ICE } & $1967 q 1-1968 q 4$ & & $1982 q 2-1983 q 3$ & $1999 q 2-1999 q 3$ & $2002 q 1$ \\
\hline & & & $1987 q 4-1989 q 2$ & & $2003 q 2$ \\
\hline & & & & & $2004 q 2$ \\
\hline & & & & & $2005 q 1$ \\
\hline & & & & & $2005 q 4-2006 q 1$ \\
\hline & & & & & $2008 q 1-2011 q 1$ \\
\hline ISR & & $1975 q 2-1977 q 2$ & $1988 q 2-1989 q 2$ & & $2000 q 4-2003 q 3$ \\
\hline \multirow[t]{2}{*}{ ITA } & & $1974 q 4-1975 q 2$ & & $1992 q 2-1993 q 3$ & $2008 q 2-2009 q 2$ \\
\hline & & $1977 q 1-1977 q 3$ & & & $2011 q 2-2014 q 2$ \\
\hline
\end{tabular}

Note: Table continues on the next page. All growth rate are demeaned, i.e. country specific growth rates are substracted from the observed growth rate.

Source: OECD calculations 
Annex F. Identified episodes of severe downturns (cont.)

\begin{tabular}{|c|c|c|c|c|c|}
\hline Countries & 1960s & 1970s & 1980s & $1990 \mathrm{~s}$ & $2000 \mathrm{~s}$ \\
\hline \multirow[t]{2}{*}{ JPN } & & $1973 q 4$ & & & $2001 q 2-2002 q 1$ \\
\hline & & & & & $2008 q 2-2009 q 1$ \\
\hline \multirow[t]{4}{*}{ KOR } & 1961q3-1962q2 & 1970q1 & 1988q2 & $1997 q 4-1998 q 2$ & $2008 q 4-2009 q 2$ \\
\hline & $1963 q 2-1963 q 4$ & $1979 q 3-1980 q 4$ & & & $2017 q 4$ \\
\hline & $1964 q 2$ & & & & \\
\hline & $1966 q 3-1966 q 4$ & & & & \\
\hline LTU & & & & & $2008 q 3-2009 q 2$ \\
\hline \multirow[t]{5}{*}{ LUX } & & $1974 q 2-1975 q 2$ & & 1996q1-1997q1 & $2001 q 2-2001 q 3$ \\
\hline & & & & & $2002 q 3-2003 q 1$ \\
\hline & & & & & $2007 q 4-2009 q 2$ \\
\hline & & & & & $2013 q 4$ \\
\hline & & & & & $2015 q 2-2016 q 2$ \\
\hline LAT & & & & & $2007 q 4-2009 q 3$ \\
\hline \multirow[t]{2}{*}{ MEX } & & & $1982 q 1-1983 q 2$ & $1995 q 1-1995 q 2$ & $2000 q 4-2002 q 2$ \\
\hline & & & & & $2008 q 3-2009 q 2$ \\
\hline \multirow[t]{2}{*}{ NLD } & $1962 q 4-1963 q 1$ & $1974 q 4-1975 q 1$ & $1980 q 1-1982 q 2$ & & $2008 q 3-2009 q 2$ \\
\hline & $1966 q 1-1966 q 2$ & $1979 q 1$ & & & \\
\hline \multirow[t]{2}{*}{ NOR } & & & $1980 q 2-1980 q 4$ & & $2008 q 1-2009 q 1$ \\
\hline & & & 1987q3-1988q2 & & \\
\hline \multirow[t]{6}{*}{ NZL } & $1961 q 4-1962 q 1$ & 1970q2-1970q4 & $1982 q 4-1983 q 1$ & 1997q4-1998q2 & $2008 q 1-2009 q 2$ \\
\hline & $1962 q 4-1964 q 1$ & $1971 q 4-1972 q 1$ & $1989 q 3$ & & $2010 q 3-2011 q 1$ \\
\hline & & 1972q3-1972q4 & & & \\
\hline & & $1973 q 2-1973 q 3$ & & & \\
\hline & & $1974 q 4-1975 q 2$ & & & \\
\hline & & $1977 q 1-1978 q 1$ & & & \\
\hline \multirow[t]{2}{*}{ POL } & & & & 1990q2-1991q2 & \\
\hline & & & & $1996 q 4$ & \\
\hline \multirow[t]{2}{*}{ POR } & & $1974 q 1-1975 q 3$ & $1983 q 1-1984 q 2$ & $1992 q 2-1993 q 1$ & $2002 q 2-2003 q 3$ \\
\hline & & & & & $2008 q 1-2009 q 1$ \\
\hline \multirow[t]{2}{*}{ RUS } & & & & $1995 q 4-1997 q 2$ & $2008 q 3-2009 q 2$ \\
\hline & & & & & $2014 q 3-2015 q 1$ \\
\hline \multirow[t]{2}{*}{ SLK } & & & & $1999 q 1-1999 q 4$ & $2008 q 1-2008 q 3$ \\
\hline & & & & & $2009 q 1-2009 q 4$ \\
\hline SLV & & & & $1990 q 1-1992 q 4$ & $2008 q 3-2010 q 1$ \\
\hline SWE & & $1976 q 2-1977 q 3$ & & $1990 q 2-1991 q 4$ & $2008 q 1-2009 q 3$ \\
\hline \multirow[t]{5}{*}{ TUR } & 1960q2-1961q2 & $1979 q 2-1980 q 1$ & $1988 q 1-1989 q 2$ & $1990 q 3$ & $2000 q 4-2001 q 4$ \\
\hline & $1965 q 1-1965 q 2$ & & & 1991q1 & $2006 q 3$ \\
\hline & & & & $1994 q 1$ & $2007 q 2-2007 q 3$ \\
\hline & & & & $1998 q 4-1999 q 4$ & $2008 q 2-2009 q 1$ \\
\hline & & & & & $2016 q^{3}$ \\
\hline \multirow[t]{2}{*}{ USA } & & 1973q3-1975q1 & $1979 q 4-1980 q 3$ & 1990q3-1991q1 & $2008 q 1-2009 q 2$ \\
\hline & & & $1981 q 2-1982 q 4$ & & \\
\hline \multirow[t]{2}{*}{ ZAF } & $1967 q 4-1968 q 3$ & $1974 q 4-1975 q 1$ & $1981 q 4-1983 q 2$ & $1989 q 3-1992 q 3$ & $2008 q 3-2009 q 3$ \\
\hline & $1969 q 4-1970 q 1$ & $1976 q 2-1978 q 2$ & $1984 q 3-1985 q 3$ & & $2015 q 2-2016 q 1$ \\
\hline
\end{tabular}

Note: All growth rate are demeaned, i.e. country specific growth rates are substracted from the observed growth rate

Source: OECD calculations 


\section{Annex G. Housing policies and resilience indicators}

\begin{tabular}{|c|c|c|c|c|c|c|}
\hline Business cycles (real GDP) & Duration (boom) & Duration (bust) & Trough-to-peak & Peak-to-trough & Strength of recovery & Time to recovery \\
\hline LTV caps & 1.0 & 1.2 & 1.8 & -1.3 & 2.0 & 0.1 \\
\hline Capital requirements & -0.8 & -0.6 & -0.3 & -1.5 & 1.6 & 0.7 \\
\hline Rent control & 0.9 & -0.4 & 0.1 & 1.0 & -0.1 & 0.7 \\
\hline Tenure security & -1.7 & -0.7 & -2.8 & 1.6 & -0.7 & 0.7 \\
\hline Social rental market & -0.2 & -0.2 & -0.9 & 0.7 & -1.4 & -0.4 \\
\hline Housing allowances & -0.5 & -1.2 & -1.3 & 1.4 & -2.3 & -1.8 \\
\hline Property taxe rate (owner) & 1.9 & 0.8 & 0.2 & 0.9 & -0.4 & -0.3 \\
\hline Property taxe rate (rental) & -0.1 & -0.8 & -1.7 & 1.9 & -0.2 & -1.9 \\
\hline Urban sprawl restrictiveness & 1.3 & -0.7 & 2.1 & 0.4 & 2.3 & -0.5 \\
\hline Densification restrictiveness & 0.0 & -0.4 & 0.1 & 0.6 & 0.5 & -1.2 \\
\hline Zoning restrictiveness & -1.2 & -0.6 & -1.3 & -0.3 & -1.9 & 0.4 \\
\hline Deviation cycles (output gap) & Duration (boom) & Duration (bust) & Trough-to-peak & Peak-to-trough & Strength of recovery & Time to recovery \\
\hline LTV caps & 1.6 & 1.5 & 0.0 & -1.6 & 1.3 & - \\
\hline Capital requirements & 0.2 & -0.5 & 1.5 & -0.6 & -0.9 & - \\
\hline Rent control & -1.6 & 1.0 & -1.2 & 1.1 & -0.8 & - \\
\hline Tenure security & 0.1 & 1.0 & 0.1 & 0.1 & 0.0 & - \\
\hline Social rental market & 0.3 & 0.7 & -1.0 & 1.3 & -0.8 & - \\
\hline Housing allowances & 1.0 & -1.9 & -1.2 & 2.1 & -1.4 & - \\
\hline Property taxe rate (owner) & 0.1 & 0.3 & -2.2 & 1.5 & -1.4 & - \\
\hline Property taxe rate (rental) & 1.0 & 1.2 & -0.6 & 1.1 & -0.5 & - \\
\hline Urban sprawl restrictiveness & -0.5 & -0.9 & 0.0 & 0.1 & 1.3 & - \\
\hline Densification restrictiveness & 0.7 & 0.3 & -0.9 & 1.0 & -1.5 & - \\
\hline Zoning restrictiveness & -1.1 & -2.8 & -1.5 & 0.9 & -0.2 & - \\
\hline Housing investment cycles & Duration (boom) & Duration (bust) & Trough-to-peak & Peak-to-trough & Strength of recovery & Time to recovery \\
\hline LTV caps & 1.2 & 0.2 & 0.2 & 0.5 & -1.8 & 1.1 \\
\hline Capital requirements & -1.0 & -1.4 & 1.3 & 0.2 & 0.7 & -1.0 \\
\hline Rent control & 0.3 & -0.2 & 1.3 & -0.7 & 1.7 & 0.5 \\
\hline Tenure security & 0.9 & 1.2 & -0.2 & 1.9 & 0.1 & 0.3 \\
\hline Social rental market & 0.4 & 1.0 & -1.7 & 1.0 & -1.3 & 0.3 \\
\hline Housing allowances & 0.1 & 0.2 & -1.6 & 1.1 & -0.7 & 1.0 \\
\hline Property taxe rate (owner) & 0.0 & 0.3 & -2.2 & 1.4 & -2.1 & 0.4 \\
\hline Property taxe rate (rental) & -0.1 & -0.2 & -2.2 & 2.7 & -0.9 & -0.9 \\
\hline Urban sprawl restrictiveness & 0.7 & -1.3 & 1.5 & 0.7 & 2.1 & 0.8 \\
\hline Densification restrictiveness & -0.6 & -0.9 & 0.3 & 0.1 & 1.5 & 0.2 \\
\hline Zoning restrictiveness & -1.9 & -0.1 & -0.5 & -0.9 & -1.2 & 1.5 \\
\hline Real house price cycles & Duration (boom) & Duration (bust) & Trough-to-peak & Peak-to-trough & Strength of recovery & Time to recovery \\
\hline LTV caps & 1.2 & -0.1 & 0.8 & -0.2 & 1.5 & -0.8 \\
\hline Capital requirements & -1.2 & -1.1 & -1.2 & 1.2 & -0.4 & -0.2 \\
\hline Rent control & 0.6 & 0.1 & 1.4 & -1.0 & -0.8 & 1.6 \\
\hline Tenure security & 1.1 & 0.3 & 1.8 & -0.5 & -0.9 & 0.9 \\
\hline Social rental market & 1.4 & 0.4 & 1.6 & -0.8 & 0.2 & -0.3 \\
\hline Housing allowances & 1.8 & 1.0 & 1.0 & 0.4 & 0.2 & 1.8 \\
\hline Property taxe rate (owner) & 1.3 & -0.4 & 0.2 & 0.0 & -0.7 & 0.1 \\
\hline Property taxe rate (rental) & 1.1 & -0.7 & 0.8 & 0.5 & -0.6 & -0.2 \\
\hline Urban sprawl restrictiveness & 0.0 & -1.7 & 0.4 & 0.9 & 2.8 & -1.2 \\
\hline Densification restrictiveness & -0.3 & -2.1 & -0.9 & 2.4 & 1.5 & -0.3 \\
\hline Zoning restrictiveness & 0.3 & 0.9 & 0.1 & -0.5 & -1.0 & 0.3 \\
\hline
\end{tabular}

Note: Cycles are obtained by searching for turning point using the Harding-Pagan (quarterly Bry-Boschan) business cycle dating procedure (Harding and Pagan, 2002[4]). Each of the characteristics of the cycle (column) is regressed one-by-one on the policy variable (row) as observed at the peak. Pooled OLS regressions are used and t-statistics reported. Bold numbers indicate significance at the $10 \%$ level. 